\title{
Ortaokul Matematik Ders Kitabı Etkinliklerinde Soyutlama Becerisinin İncelenmesi
}

\author{
Investigation of Abstraction Skill in Middle School \\ Mathematics Textbook Activities
}

\begin{abstract}
Elif KILIÇOĞLU*
Öz: Bu çalışmada ortaokul matematik ders kitaplarında soyutlama becerisine ne sıklıkla yer verildiğinin ortaya koyulması amaçlanmıştır. Bu amaçla Milli Eğitim Bakanlı̆̆ı'nca önerilen ve Hatay'da kullanımı tercih edilen ders kitapları çalışma grubu olarak kullanılmış ve toplamda 157 etkinlik incelenmiștir. Çalışmada nitel araştırma yöntemlerinden doküman incelemesi kullanılmış olup elde edilen dokümanlara betimsel analiz uygulanmıştır.Etkinliklerin birçoğunda soyutlama ile ilgili karşılaştırma, yansıtma, farkındalık, sentezleme ve genelleme gibi bilişsel kavramlara rastlansa da pek azının (\%12.7) soyutlama becerisini geniş ölçüde sağladığı ifade edilebilir. Elde edilen bulguları sınıf bazında değerlendirecek olursak, 6. sınıf etkinliklerinin (\%31) soyutlama becerisini diğer sınıfların etkinliklerine nazaran daha iyi temsil ettiği fark edilmiștir. Ayrıca geometri ve ölçmede soyutlama becerisini ortaya çıkarmaya yönelik eylemlerin diğer öğrenme alanlarına kıyasla daha çok yer verildiği tespit edilmiştir. Sonuç olarak müfredatın önerdiği ve problem çözme, ispat yapma, ilişkilendirme gibi matematiğin etkili yapılandırılması için gerekli olan soyutlama becerisinin, ders kitaplarında yeteri kadar yer bulmadığı belirlenmişstir.
\end{abstract}

Anahtar Kelimeler: Matematiksel soyutlama, soyutlama becerisi, ders kitabı, matematiksel etkinlik, doküman incelemesi

Abstract: In this study, it was aimed to determine how frequently abstraction skills were included in
mathematics textbooks. For this purpose, the textbooks recommended by the Ministry of National
Education and preferred to be used in Hatay were used as the study group and a total of 157 activities were
examined. Document review, one of the qualitative research methods, was used in the study, and descriptive
analysis was applied to the documents. Although most of the activities have cognitive concepts such as
comparison, reflection, awareness, synthesizing and generalization related to abstraction, few $(12.7 \%)$ can
provide abstraction skills. It is realized that 6th grade activities (31\%) represent the abstraction ability better
than the activities of other grades. It was determined that the actions aimed at elucidating the abstraction
ability in geometry and measurement was given more place than the other learning domains. As a result, it
was determined that the abstraction skills suggested by the curriculum, which are necessary for effective
structuring of mathematics such as problem solving, proving, and relating, did not have enough space in
the textbooks.

Keywords: Mathematical abstraction, abstraction skill, textbook, mathematical activity, document review

\section{Giriş}

Eğitim sistemleri ülkeden ülkeye değiş̧iklik göstermektedir. Dahası ülkelerin eğitim sistemleri okuldan okula ya da sınıftan sınıfa bile değişiklik gösterebilmektedir. Bu değişim içerisinde elbette ortak olarak kullanılan materyaller de vardır. Ders kitapları bu materyallerden biridir. Ders kitapları eğitim-öğretim faaliyetlerinde en sık kullanılan yazılı materyallerdendir ve özellikle müfredatın uygulama boyutu olduğu için sadece sınıf içinde kalmayıp eğitim politikalarını da şekillendiren bir unsur olarak karşımıza çıkmaktadır (Akdeniz, 2004). Nitekim yazılı dokümanların incelenip sonuçlarının sunulması ile öğretimi iyileştirme çalışmaların yapıldığı ve bu sonuçlara istinaden eğitim reformlarının gerçekleştirildiği düşünülmektedir.

Ders kitapları üzerinde yapılan çalışmaların geçmişi pek eskiye dayanmamaktadır. Nitekim Fan'a (2011) göre ilk olarak 1955 yılında bu konuda çalışmalar başlamış ve giderek ivme

*Dr. Öğretim Üyesi, Hatay Mustafa Kemal Üniversitesi, Eğitim Fakültesi, Hatay-Türkiye, ORCID:0000-0001-79044310 ,e-posta: elifacil@ mku.edu.tr 
kazanmış, özellikle son 30 yılda çalışmaların yoğunlaştığı ifade edilmiştir. Fakat milattan önce 3000'li yıllarda yapılmış kil tabletler dünyanın ilk ders kitapları olarak kabul görmektedir (Kaya, 2002). Yani bu konuda yapılan çalışmalar henüz yeni olsa da ders kitaplarının kullanımının çok eskilere dayanmadığı ifade edilebilir. Özel olarak matematikte Öklit'in Elementler kitabı düşünüldüğünde ders kitaplarının çok eski zamanlardan beri kullanıldığı söylenebilir. Ülkelerin eğitim politikaları ile şekillenen ders kitaplarının kullanımının bu kadar eski olup çalışmalarının yeni olması da dikkat çekicidir.

Ders kitapları ilgili olduğu alanın öğretim faaliyetlerinde bir filmin ana karakteri özelliğine sahiptir. Eğitim-öğretim faaliyetlerinde bu denli önemli yere sahip bir materyalin hazırlanması elbette kolay bir süreç değildir. Ders kitaplarını; sağlayacağı avantajlar, ortaya çıkaracağı olumsuz durumlar, hedeflenen kazanımlar, sosyal çevre, ekonomik durum ve ülkenin koşulları gibi farklı bileşenler ile birlikte ele alarak, bir ekip çalışması sonucunda ortaya çıkarılan öğretim ürünü olarak ifade edebiliriz. Görüldüğü gibi ders kitabı hazırlama, ortak çalışma alanlarının gerekli olduğu karmaşı ve dinamik bir süreci ifade etmektedir.

Ders kitapları konu kapsayıcılığı, sosyal ve ekonomik değerler, cinsiyet algısı, değerler eğitimi, bilişsel, duyuşsal ve psikomotor beceriler gibi çeşitli yönlerden ele alınarak analiz edilmiştir (bkz. Çavuş, Erdem, Gürbüz ve Şahin, 2017; Çimen ve Yıldız, 2017; Deniz ve Karagöl, 2018; Gümüşoğlu, 2014). Bu analiz özellikle kitapların güncellenmesi ile zaman zaman tekrarlanmıştır. 1999 yılında Ayvacı, Çepni ve Akdeniz tarafından yapılan çalışmada ülkemizde geliştirilen kitapların öğrencilerin ve öğretmenlerin beklentilerini karşılamadığ 1 , güncellik, soyut konuların zihinde canlandırılması ve araştırma yapmaya yönlendirme gibi özellikleri hedeflenen düzeyde yansıtmadığı ortaya koyulmuştur. Oysaki 2000'li yıllarda yapılan çalışmalarda ders kitaplarının başarıyı belirlemede etkili olduğu ifade edilmektedir (Altun, Arslan ve Yazgan, 2004; Fan, 2013; Herbel-Eisenmann, 2007; Kılıç ve Seven, 2002; Yaşar, 2005). Bu çelişkiler ders kitaplarının analiz edilmesini gerekli k1lmaktadır. Smith III, Males, Dietiker, Lee ve Mosier'a (2013) göre ders kitaplarının incelenmesi öğrenci öğrenmesi için gerekli ve değerlidir. Diğer yandan Johansson (2003) öğrenci öğrenmesinin ötesindeders kitaplarının incelenmesi ile elde edilen sonuçların eğitim politikalarını etkileyeceğini ifade etmektedir. Ayrıca bu çalışmada kitap incelemesi özel olarak matematik disiplini çerçevesinde yapılmış olup, matematiksel soyutlama ile ilgili veriler bulunmaktadır. Matematiksel soyutlama önceden ilişkisiz gibi duran bilgi parçalarının mantıksal ve zihinsel oluşumlarla birleştirilmesidir (Noss ve Hoyles, 1996). Ders kitabının matematiksel soyutlama becerisi çerçevesinde analiz edilmesi, soyutlama kavramı hakkında öğretmenlere, araştırmacılara, eğitimcilere sağlayacağı farkındalık bakımından değerli görülmektedir. $\mathrm{Bu}$ araştırmada ortaokul matematik ders kitaplarındaki ekinliklerin öğrencilerin soyutlama becerisini kullanmalarına ne derecede imkân verdiği incelenmeye çalışılmıştır. Araştırmanın amacı doğrultusunda cevap aranan problemler şu şekildedir:

1. Soyutlama becerisi ortaokul matematik etkinliklerinde hangi sıklıkta yer almaktadır?

2. Ortaokul matematik öğrenme alanları etkinliklerinin, soyutlama eylemlerini temsil etme durumları nelerdir?

\section{Kuramsal Çerçeve}

\section{Müfredatın uygulamadaki Yüzz̈: Ders kitaplart}

Bilgi çağının hızla gelişimi ile Türkiye'nin uzun ve kısa vadeli eğitim planı öğrenci merkezli ve öğretmen rehberli eğitimi savunmaktadır. Sadece Türkiye değil tüm ülkeler bunu kaliteli işçi üretimini sağlamak adına yetenekli bireyler, ileri teknolojik gelişimler için profesyonel yetenekler ve yaratıcı liderler yetiştirmek ve dolayısıyla kalkınma planını oluşturmak için yaparlar. Valverde, Bianchi, Wolfe, Schmidt ve Houang (2002), eğitim reformlarının müfredat bilgisi ve müfredat bilgisinin somut göstergeleri olan ders kitapları ile şekillendiğini savunurlar. Özellikle bu konuda yapılan çalışmaların sonuçlarının reform hareketlerine önemli ölçüde katkıda bulunduğunu iddia ederler.

Ders kitapları, eğitim-öğretim faaliyetlerinin yürütülmesinde kullanılan, işlenecek konunun içeriğine göre hazırlanmış, hem öğretmen hem de öğrencilere yardımcı yazılı 
dokümanlardır. Stray (1994) ise ders kitaplarını, bilginin yetkili pedagojik versiyonunu sağlamak için geliştirilen kitaplar, olarak tanımlamaktadır. Stein, Remillard ve Smith (2007) ders kitaplarının resmi ve yazılı müfredat olarak düşünülebileceğini ifade etmektedirler. Öğretmenler eğitim-öğretim sürecindeki etkinlikleri ya da görevleri ders kitaplarından seçtikleri için müfredatın gerçekleştirilmesinde ders kitapları önemli bir rol oynamaktadır. Ders kitapları öğretmenlerin ders içeriğini belirlemelerinde onlara yardımcı olması ve hatta öğrencilerin öze dönük denetim yapmalarına imkân sağlaması bakımından oldukça önemlidir (Brousseau, 1986). Ders kitapları özellikle matematik gibi uygulamalı derslerde sınıf içi uygulamalarla yakından ilişkili olduğu için daha da anlamlı bir görev üstlenmektedir. Johansson'a (2003) göre ders kitapları, uygun örnek ve etkinliklerle dersin nasıl şekilleneceğini belirlemek, konuları öğrenci seviyesine göre sıralamak, müfredat konusunda da güncel reformların yapılmasına öncülük etmek, öğretmenlere ve öğrencilere ve hatta ebeveynlere matematiğin yorumlanması konusunda yardımcı olmak gibi avantajlar sunar. Eğitim-öğretim uygulamalarında hedeflenen başarıyı yakalamak için sadece ders kitaplarını göz önünde bulundurmak doğru değildir. Çünkü başarı durumunun öğretmen bilgisi, öğretmen ve öğrencilerin inançları, tutumları, yeterlilikleri, fiziki koşullar, ebeveyn etkisi, sosyal çevre gibi pek çok nedenle açıklanabileceği aşikârdır. Fakat ders kitabındaki sınırlılıkların ortaya koyulması, öğrencinin öğrenme firsatlarını sınırlayan durumları azaltabilir ya da öğrenmede zorlandığı noktaların belirlenmesinde ve giderilmesinde yardımcı olabilir (Smith III, Males, Dietiker, Lee ve Mosier, 2013).

Ülkemizde aktif şekilde kullanılan ders kitapları Talim Terbiye Kurulu tarafından onay almış kitaplardır. Kullanılacak kitapların seçiminde Milli Eğitim Bakanlığı'nın (MEB) hazırlamış olduğu esas ve yönergeler belirleyicidir. MEB Kitapları İnceleme Komisyonu, yayın evleri tarafından kendilerine gönderilen kitapları inceler ve uygun olduğuna dair bir rapor hazırlar. $\mathrm{Bu}$ inceleme işlemi basit bir süreç değildir, kitabın içeriği, biçimsel özellikleri gibi farklı yönlerden ilgili uzmanlar tarafından detaylı bir şekilde gözden geçirilirler. İncelemede özellikle müfredat açısından kapsayıcılık dikkate alınır. Yani ders kitaplarının kazanımları ve becerileri ne derece yansıttıkları onay almaları için önemlidir. Eğitim-öğretim açısından uygun bulunan kitaplar Tebliğler Dergisi'nde yayımlanarak ilan edilirler (MEB, 2012). Alan yazında ders kitaplarının çeşitli değişkenlere göre incelemesini ya da öğretimde etkililiğini araştıran, öğretmen, öğrenci gibi bu kitapları kullanan kitlenin görüşlerinin alındığı çeşitli çalışmalar yer almaktadır. Örneğin, Zeybek, Üstün ve Birol (2018) tarafindan yapılan çalışmada matematik ders kitaplarında ispat yapma becerisinin yeri incelenmiştir. Nitel yöntemle yapılan bu çalışma ile ders kitaplarında yer alan ispat özelliği taşıyan etkinliklerin sayısının, mevcut müfredatın hedeflediği yapı ile uyuşmadığı tespit edilmiştir. Diğer bir çalışma ise Ubuz ve Sarpkaya (2014) tarafından yapılmıştır. Bu çalışmada 6. sınıf cebirsel görevlerin bilişsel istem düzeylerine göre analizi yapılmış ve ders kitaplarındaki etkinliklerin bilişsel istem düzeylerinin yüksek olmasına karşın sınıf içi uygulamaların etkinlik seviyelerini düşürdüğü ortaya çıarılmıştır.

Ders kitaplarının eğitimde başlıca bir materyal olarak kullanılması elbette doğru değildir. Özellikle günümüzde gelişen teknoloji ile birlikte ders kitaplarının farklı materyallerle desteklenerek zenginleştirilmesinin, öğretimdeki başarıyısağlamada etkili bir yol olduğu düşünülmektedir. Nitekim Johnson (1990) çalışmasında ders kitaplarının öğrenci seviyesine göre hazırlanmasını ve öğretmen tarafından bilinçli bir şekilde kullanılmasını pozitif, fakat öğretim sürecinin başlıca kaynağı olarak kullanılmasını ise negatif olarak değerlendirmektedir.

\section{Matematiksel soyutlama becerisi}

Matematik soyut ve anlaşılması herkes için aynı ve kolay olmayan bir bilim dalıdır. Yani matematiği anlamak fenomene bağlıdır ve farklılık gösterebilir. Bu durum matematiği özel ve önemli k1lmaktadır. İnsanoğlu anaokulundan lisansüstü eğitime dek matematiğin gerekliliği konusunda hemfikirdir. Özellikle ebeveynler çocuklarının gelişimlerini matematik bilgisi ile paralel tutmaktadırlar. Bunun bir önyarg1 olmas1 yaygın bir yarg1 olmasının önüne geçememektedir. Matematiğin anlaşılmasındaki zorluğun en belirgin algısı da soyut yapıda olmasıdır diyebiliriz (Iş̧ı ve Konyalıŏlu, 2005). Soyut yapıların anlaşılması için öncelikle zihinsel yapılandırmaya ihtiyaç duyulur. Matematiğin herkes için aynı kolaylıkta olmaması, 
zihinsel yapılandırma sürecinin de her birey için farklı zorlukta olmasıyla eş değerdir. Matematiksel anlamayı sağlamada ihtiyaç duyulan zihinsel yapılandırma sürecini gerçekleştirmek matematiksel başarı ile sonuçlanır. $O$ halde bu bahsi geçen zihinsel yapılandırmayı nasıl başarabiliriz? Bu sorunun pek çok yanıtı olabilir ama şüphesiz ki genel kanılardan biri matematiksel becerilerin öğrencilere kazandırılmasıdır. Nitekim Olkun ve Toluk Uçar (2012) matematiksel anlamın gelişiminin ancak öğrenenin zihinsel aktifliği ile mümkün olduğunu ve becerilerin bu süreçte kritik öneme sahip olduğunu dile getirmişlerdir.

Beceri kelime anlamı olarak bireyin bir işlemi amaca uygun olarak sonuçlandırma yeteneği olarak ifade edilmektedir (Türk Dil Kurumu, 2019). Matematikte ise daha verimli ve etkili öğrenme sağlanması için bireye kazandırılması hedeflenen farklı beceriler vardır. Bunlar problem çözme, ilişkilendirme, iletişim, model oluşturma, soyutlama, ispatlama gibi becerilerdir. $\mathrm{Bu}$ becerilerin kendine özel açıklamaları olmakla birlikte hepsinin ortak noktası matematiksel anlamın sağlanmasına yönelik yardımcı bileşenler olmalarıdır. Bir becerinin diğerine göre üstünlüğü olmamakla birlikte birbirlerinin ortaya çıkmasında yardımcı rol üstlenirler. Örneğin ilişkilendirme becerisi problem çözme ya da ispatlama becerisi için yeterli olmasa da gerekli bir beceridir. Matematiksel becerilerden ve bu becerilerin öğrencilere kazandırılmasından 1739 sayılı Millî Eğitim Temel Kanunu'nda belirlenmiş olan Matematik Dersi Öğretim Programı'nın genel amaçlar kısmında özellikle bahsedilmiştir. Öğretim programlarının hazırlanışındaki genel amaç en az temel düzeyde beceri ve yetkinliğe sahip bireyler yetiştirmektir (MEB, 2018). Bu yüzden öğretim programları beceri kazandırma odaklı hazırlanır. Chambers ve Timlin (2013) ortaokulda matematik öğretimi için hazırlamış oldukları kitapta, programın uygulanmasındaki verimlilikte becerilerin önemli bir yerinin olduğuna değinmişlerdir.

Matematik müfredatı yapısalcılıkla ilgilidir ve yapısalcı yaklaşıma göre matematiği anlamak ancak bireyin matematiksel bilgiyi kendisinin oluşturması ile mümkündür. Öğrenenin kendi bilgisini oluşturması ve yeni bilgilerini eski bilgileri üzerine inşa etmesi ancak o bilgiyi soyutlaması ile mümkün olmaktadır. Bir bilginin soyutlanması yapısında pek çok matematiksel beceriyi barındırmaktadır. Örneğin, fonksiyon bilgisinin soyutlanması demek bu kavramın denklem, bağıntı, küme bilgisi ile yüksek düzeyde ilişkilendirilmesi demektir. Yeni bir kavramın oluşturulması demek, oluşturulan bilginin gerçekten doğru olduğundan emin olmak demektir. Bunlar matematikte ileri düzeyde iletişim bilgisine sahip olmakla eş değerdir. Görüldüğü gibi soyutlama becerisi pek çok beceri ile iç içe anlam oluşturmuş komplike bir yapıdadır. Dienes'e (1967) göre soyutlama, bireyin önceden oluşturduğu yapıları yenileri ile ilişkilendiren aktivitelerle dolu dinamik bir süreçtir. Soyutlama aslında bir indirgeme, basitleştirme ve daha geniş uygulamalara genelleme sürecidir (Yılmaz, 2011) ve bilinir ki bu kavramlar hedeflenen bilginin kazanılması için önemlidir.

Soyutlama ile ilgilenen araştırmacıların hem fikir oldukları nokta, bu kavramın çok yönlü olmasından dolayı zorlu bir süreci ifade etmesidir. Dubinsky (1991) soyutlamanın basit bir süreç olmadığını, bu sürecin ancak parçalara ayrılarak, genelleme, sentezleme ve soyutlama olmak üzere üç kavram ile açıklanabileceğini ifade etmiştir. Bunların bir döngü olarak soyutlamayı gerçekleştirdiklerini ortaya koyan Dubinsky, 2000 yılında yaptığı araştırma ile bu konudaki fikirlerine daha da derinlik kazandırmıştır ve soyutlamayı açıklamak için içselleştirme, koordine etme, enkapsülasyon, genelleme, tersine çevirme olmak üzere beş kavram üzerinde durmuştur. Dubinsky (2000) bu kavramları soyutlamanın gerçekleştirilmesinde kullanılan bilişsel mekanizmalar olarak isimlendirmiştir. Tablo 1'de yer alan anahtar kelimeler her bir bilişsel mekanizmayı özetleyen yapıyı temsil etmektedir (Açı1, 2015).

Tablo 1.

Bilișsel Mekanizmalarla İlgili Anahtar Kelimeler

\begin{tabular}{|c|c|c|c|c|}
\hline İçselleştirme & Koordine etme & Enkapsülasyon & Genelleme & $\begin{array}{l}\text { Tersine } \\
\text { Çevirme }\end{array}$ \\
\hline
\end{tabular}




\begin{tabular}{|c|c|c|c|c|}
\hline $\begin{array}{l}\text { - Karşılaştırma } \\
\text { - Yansitma } \\
\text { - Farkına varma } \\
\text { - İçsel } \\
\text { betimleme } \\
\text { - Tanımlama }\end{array}$ & $\begin{array}{l}\text { - Bütünleştirme } \\
\text { - Kompozisyon } \\
\text { - Bir arada } \\
\text { düşünme }\end{array}$ & $\begin{array}{l}\text { - Sentezleme } \\
\text { - Muhafaza } \\
\text { etme }\end{array}$ & $\begin{array}{ll}\text { - } & \text { Daha geniş } \\
& \text { uygulanabilirlik } \\
\text { - Oluşan yapının } & \text { uygulanabilirliği } \\
\text { hakkında } \\
\text { farkındalık } \\
\text { - İlişkilendirme } \\
\text { - Araştırma } \\
\text { (Benzerlikleri } \\
\text { ilişkilendirme) }\end{array}$ & $\begin{array}{l}\text { • Geri } \\
\text { dönüşümlülük }\end{array}$ \\
\hline
\end{tabular}

İçselleştirme bireyin içsel anlamları oluşturmak için yansıtıcı soyutlamalar yapması iken, koordine etme oluşturulması hedeflenen yapılar için iki ya da daha fazla sürecin bir arada düşünülmesini ifade etmektedir. Enkapsülasyon var olan bilgi üzerine yenisini inşa etmekle alakalıdır. Genelleme bilgi kümelerinden şemalara ulaşmayı hedef alırken, tersine çevirme oluşturulan yapının içselleştirilmesi ile tersten düşünülebilmesi yani bireyin elde edilen bilginin geri dönüşüp dönüşemediği bilgisini kazanması ile ilgilidir.

Matematiksel soyutlama ile ilgili yapılan çalışmaların, özel olarak seçilen bir kavramın yapılandırılmasına yönelik yoğunlaştı̆̆ fark edilmiştir. Örneğin, Tsamir ve Dreyfus (2002) sonsuz kümeler konusunda, Murray (2002) fonksiyon konusunda, Özmantar (2004) fonksiyon grafikleri konusunda ve Tabaghi (2007) ise logaritma konusunda lise çağı öğrencilerin matematiksel soyutlama süreçlerini incelemişlerdir. Diğer yandan öğretmen adayları ile çalışan Çetin (2009) limit konusunda ve Weller, Arnon ve Dubinsky (2009) rasyonel sayılar konusunda öğrencilerin soyutlama süreçlerini ortaya çıkarmaya çalışmışlardır. Yapılan çalışmalardan anlaşılacağı üzere, soyutlama süreçlerinin analizinin genel olarak 15 yaş üzeri öğrenenler üzerinde yoğunlaştığ 1 ifade edilebilir. Fakat soyutlama sürecinin anaokulu düzeyinde dahi sorgulanabileceği fikri (Piaget, 1970, akt. Ferrari, 2003), son zamanlarda yapılan çalışmaların örneklemini etkilediğini göstermektedir. Ayrıca soyutlama becerisinin Ulusal Matematik Öğretmenleri Konseyi (National Council of Teachers of Mathematics [NCTM], 2000) tarafından ifade edilen ve ilköğretim matematiği için gerekli olan problem çözme, ispat, ilişkilendirme gibi süreç standartlarını yapısında bulundurması, araştırmaların ilköğretimde de yapılabilirliği düşüncesini desteklemektedir. Bu durumlar çalışmaların ilkokul ve ortaokul düzeyinde de yaygınlaşmasına zemin hazırlamıştır. Örneğin, Açıl (2015) ortaokul 7. sınıf öğrencileri ile yaptığı tez çalışmasında, öğrencilerindenklem kavramını oluşturma/soyutlama süreçleri incelemiştir. Camci (2018) prizmaların hacmi konusunda 6. sınıf öğrencilerinin; Altaylı (2018) ise çokgenler konusunda 7. sınıf öğrencilerinin soyutlama süreçlerini incelemişlerdir. Bu çalışmaların sonuçları öğrencilerin bazı durumlarda derin matematiksel soyutlama yapabildiklerini göstermektedir.

\section{Yöntem}

$\mathrm{Bu}$ çalışmanın amacı matematiksel soyutlama becerisinin ders kitaplarında kullanım sıklığını ortaya koymaktır. Nitel araştırma yaklaşımının benimsendiği çalışmada verilerin toplanmasında doküman incelemesi yöntemi kullanılmıştır. Doküman incelemesi, doküman olarak nitelendirilen belgelerinsistematik olarak analiz edilmesi (Wach ve Ward, 2013) ve ilgili konu hakkında anlamsal çıkarımlar yapılması (Corbin ve Strauss, 2008) için kullanılan bir nitel araştırma yöntemidir. Bu çalışmada ortaokul matematik ders kitabında yer alan etkinlikler birer doküman olarak kullanılmış olup, bu etkinlikler çerçevesinde soyutlama becerisi ile ilgili anlamsal çıkarımlar yapılmıştır.

\section{Çalışma grubu}


Hatay ili bölgesinde Milli Eğitim Bakanlığı tarafından 2018-2019 eğitim öğretim yılında kullanımı önerilen 5., 6., 7. ve 8. sinıf matematik ders kitaplarında yer alan tüm etkinlikler araştırmanın çalışma grubunu oluşturmaktadır. 5. sınıf için SDR Dikey; 6. sınıf için Berkay; 7. sınıf için Koza; 8. sınıf için Ekoyay Yayınları'nın hazırlamış oldukları matematik kitapları incelenmiştir (MEB, 2018). Matematik ders kitabında 5. sinıfta 45 etkinlik, 6. sinıfta 42 etkinlik, 7. sınıfta 47 etkinlik ve 8 . sınıfta 23 etkinlik olduğu tespit edilmiştir. Dolayısıyla toplamda 157 etkinlik araştırmanın çalışma grubunu oluşturmuştur.

\section{Veri toplama aracı ve süreci}

Ortaokul matematik ders kitaplarında yer alan etkinliklerin incelenmesini amaçlayan bu çalışmada öncelikle etkinliklerin künyesi belirlenmiştir. Yani etkinliklerin hangi öğrenme alanına, hangi üniteye ve hangi konuya dâhil olduğu belirlenmiş ve kolaylık sağlaması açısından sayfa numaraları ile birlikte kaydedilmiştir. Etkinliklerin belirgin olması açısından her birine kısa isim verilmiştir. Mesela 5. sınıfın birinci etkinliği için $E_{5} 1$, ikinci etkinliği için $E_{5} 2$ gibi isimlendirme yapılmıştır. Benzer şekilde 6 . sınıf etkinlikleri için $E_{6} 1, E_{6} 2, \ldots ; 7$. sınıf etkinlikleri için $E_{7} 1, E_{7} 2, \ldots ; 8$. sinıf etkinlikleri için ise $E_{8} 1, E_{8} 2, \ldots$ gibi isimlendirmeler gerçekleştirilmiştir. Daha sonra etkinliklerin künyesinin yer aldığ betimsel tablolar oluşturulmuştur. Bu tablolara ait örnek şablon 7. sınıf için Tablo 2'de verilmiştir.

Tablo 2.

Etkinliklerin Künyesi

\begin{tabular}{|c|c|c|c|c|c|}
\hline Sinif & $\begin{array}{c}\text { Ünite } \\
\text { No }\end{array}$ & Ünite $\mathrm{Ad}_{1}$ & Konular & Etkinlik Adı (Sayfa No) & Toplam \\
\hline & ص & 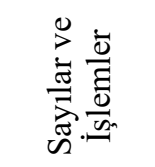 & Tam Sayılarla İşlemler & $\begin{array}{c}E_{7} 1(17), E_{7} 2(26), E_{7} 3(30), E_{7} 4 \\
(37) \\
E_{7} 5(41)\end{array}$ & 5 \\
\hline
\end{tabular}

\begin{tabular}{|c|c|c|c|c|}
\hline \multirow{3}{*}{ 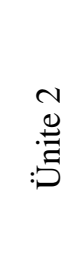 } & \multirow{3}{*}{ 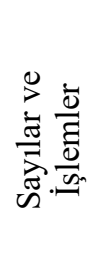 } & Rasyonel Sayılar & & \multirow{3}{*}{9} \\
\hline & & & $E_{7} 6(54), E_{7} 7(58), E_{7} 8(62)$ & \\
\hline & & $\begin{array}{l}\text { Rasyonel Sayılarla } \\
\text { İşlemler }\end{array}$ & $\begin{array}{c}E_{7} 9(67), E_{7} 10(72), E_{7} 11(80) \\
E_{7} 12(85), E_{7} 13(87), E_{7} 14(91)\end{array}$ & \\
\hline \multirow{2}{*}{$\stackrel{m}{\stackrel{n}{\Xi}}$} & \multirow{2}{*}{ ن } & Cebirsel İfadeler & $\begin{array}{c}E_{7} 15(105), E_{7} 16(107), E_{7} 17 \\
(111)\end{array}$ & \multirow{2}{*}{6} \\
\hline & & Eşitlik ve Denklem & $\begin{array}{c}E_{7} 18(115), E_{7} 19(118), E_{7} 20 \\
(123)\end{array}$ & \\
\hline \multirow{2}{*}{$\stackrel{Ð}{\stackrel{\bullet}{\Xi}}$} & \multirow{2}{*}{ 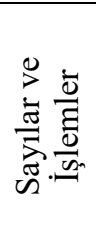 } & Oran ve Orant1 & $\begin{array}{c}E_{7} 21(133), E_{7} 22(135), E_{7} 23 \\
(140) \\
E_{7} 24(144), E_{7} 25(147)\end{array}$ & \multirow{2}{*}{10} \\
\hline & & Yüzdeler & $\begin{array}{c}E_{7} 26(156), E_{7} 27(156), E_{7} 28 \\
(156) \\
E_{7} 29(159), E_{7} 30(163)\end{array}$ & \\
\hline \multirow{3}{*}{$\stackrel{n}{: \mathscr{n}}$} & \multirow{3}{*}{ 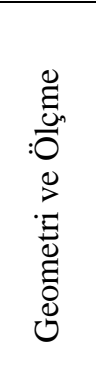 } & Doğrular ve Açılar & $E_{7} 31(173), E_{7} 32(179)$ & \multirow{3}{*}{11} \\
\hline & & Çokgenler & $\begin{aligned} E_{7} 33(184), & E_{7} 34(191), E_{7} 35 \\
& (196) \\
E_{7} 36(205), & E_{7} 37(205), E_{7} 38 \\
& (210)\end{aligned}$ & \\
\hline & & Çember ve Daire & $\begin{array}{c}E_{7} 39(216), E_{7} 40(220), E_{7} 41 \\
(224)\end{array}$ & \\
\hline
\end{tabular}




\begin{tabular}{|c|c|c|c|c|}
\hline \multirow{2}{*}{ 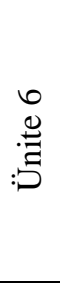 } & \multirow{2}{*}{$\frac{\stackrel{0}{E}}{\frac{0}{0}}$} & Veri Analizi & $\begin{array}{c}E_{7} 42(240), E_{7} 43(248), E_{7} 44 \\
(252) \\
E_{7} 45(257)\end{array}$ & \multirow[t]{2}{*}{6} \\
\hline & & $\begin{array}{l}\text { Geometri ve Ölçme- } \\
\text { Cisimlerin Farklı } \\
\text { yönlerden Görünümleri }\end{array}$ & $E_{7} 46(261), E_{7} 47(263)$ & \\
\hline
\end{tabular}

Tablo 2'de 7. sınıfa ait 47 etkinliğin künyesi yer almaktadır. Örneğin $E_{7} 26$ numaralı etkinlik ders kitabının sayılar ve işlemler öğrenme alanının 4. ünitesinde yer alan yüzdeler konusu ile ilgili olup sayfa 156 'da bulunmaktadır. Diğer sınıf düzeylerine ait etkinlik rehberleri de benzer şekilde hazırlanmış ve araştırmanın amacını gerçekleştirmek üzere etkinlikler analiz edilmiştir. Ayrıca bu çalışma bilimsel araştırma ve yayın etiğine aykırı eylemlerden uzak bir şekilde tamamlanmıştır.

\section{Veri analizi}

Araştırmada incelenen dokümanlar betimsel analiz yöntemine göre analiz edilmiştir. Betimsel analiz, verilerin daha önceden belirlenen kategorilere göre özetlenmesi ve yorumlanmana dayalı bir nitel analiz yöntemidir (Yıldırım ve Şimşek, 2011). Etkinliklerin analiz edilmesinde Tablo 1'de yer alan ve Dubinsky (2000) tarafından geliştirilen soyutlama fikrini ortaya çıkarmayı amaçlayan bilişsel mekanizmalar birer kategori olarak kullanılmıştır. Verilerin analizinde öncelikle etkinlikler genel olarak incelenmiş ve içeriklerine ait kodlar oluşturulmuştur. $\mathrm{Bu}$ kodların bilişsel mekanizmalardaki anahtar kelimelerle uyumuna bakılmış ve her bir etkinliğin hangi kategori altında değerlendirileceğine karar verilmiş̧ir. Elde edilen veriler aşağıdaki tabloda her bir sınıf düzeyi için için ayrı ayrı örneklendirilmiştir (Tablo 3). Tersine çevirme ile ilgili her hangi bir etkinlik tespit edilemediği için örnek verilmemiştir.

Tablo 3.

Etkinlik Analizleri

\begin{tabular}{|c|c|c|}
\hline Etkinlik No & Kodlar & Kategoriler \\
\hline$E_{5} 20$ & $\begin{array}{l}\text {-Tanımlama } \\
\text {-Farklı gösterim } \\
\text {-Karş1laştırma } \\
\text {-Strateji açıklama } \\
\text {-Betimleme }\end{array}$ & -İçselleştirme \\
\hline$E_{6} 1$ & $\begin{array}{l}\text {-Plan yapma } \\
\text {-Tahmin etme } \\
\text {-Kontrol etme (sağlama) } \\
\text {-Farklı stratejileri karşılaştırma } \\
\text {-Bir arada düşünme }\end{array}$ & -Koordine etme \\
\hline$E_{7} 35$ & $\begin{array}{l}\text {-Özellik bulma } \\
\text {-Karş1laştırma } \\
\text {-Bir arada düşünme } \\
\text {-Sentezleme } \\
\text {-İlişkilendirme }\end{array}$ & -Enkapsülasyon \\
\hline$E_{8} 13$ & $\begin{array}{l}\text {-Karşılaştırma } \\
\text {-Farklı kavramları dikkate alma } \\
\text {-Planlama } \\
\text {-Aşamalı düşünme } \\
\text {-Kural oluşturma } \\
\text {-Değerlendirme }\end{array}$ & -Genelleme \\
\hline
\end{tabular}


Tablo 3'te 6. sınıf matematik ders kitabına ait ilk iki etkinliğin analizi yer almaktadır.

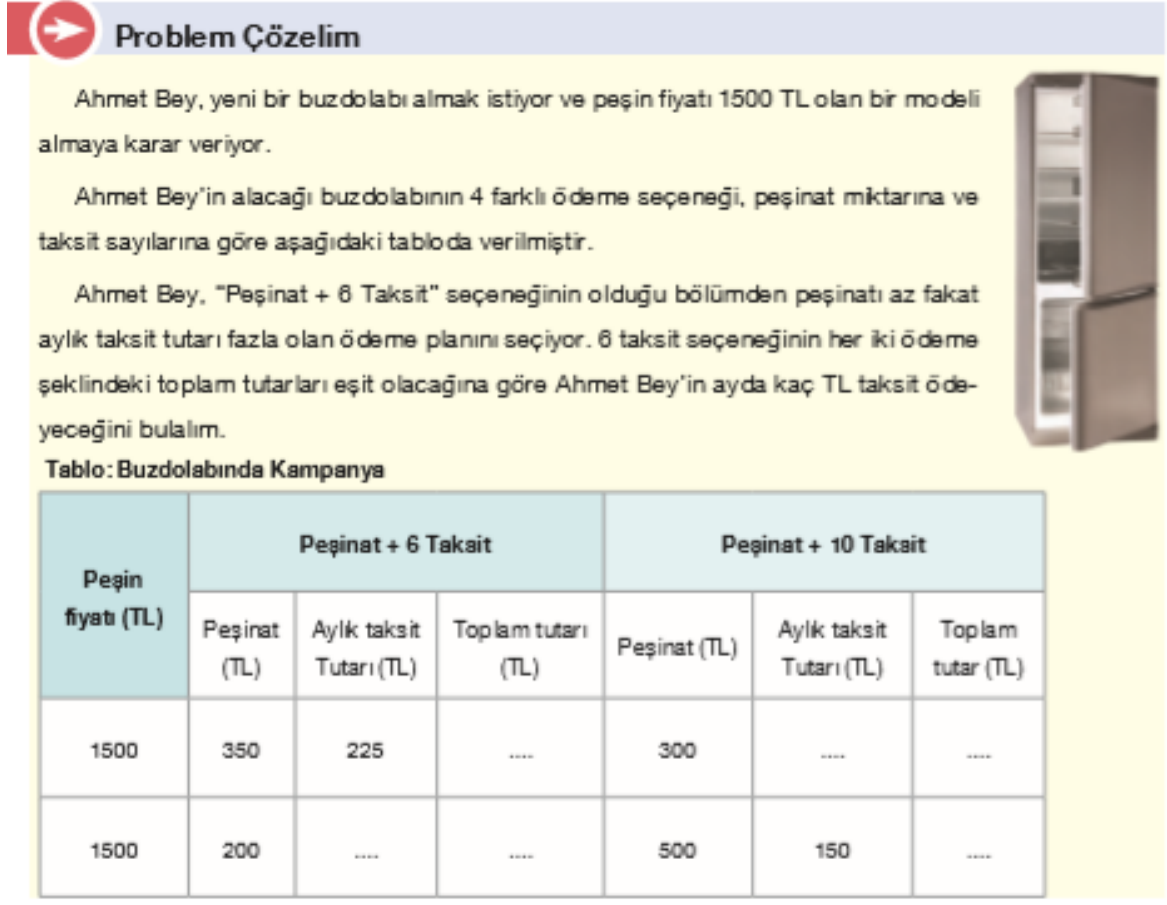

\section{Etkinlik}

Problem Çōzelim

- Yukarıda ödeme seçenekleri verilen tabloyu inceleyelim.

- Problemi çözmek için kullanacaḡımı çözüm stratejilerine ujgun bri plan yapalım ve sonucu tahmin edelim.

- Planimiza uygun olarak problemi çözelim.

- Problemin sonucunu kontrol edelim ve tahminimizle karșlaștralım.

$\rightarrow$ Problemin çözûmūnū, sınff arka dașlarınııı çözümleri ile karșılaștrınız. Farklı çözūm stratejilerini tartı̣̄ınz.

Şekil 1. 6. sınıf matematik ders kitabından örnek bir etkinlik- $E_{6} 1$ (MEB, 2018, s. 30)

Şekil 1'de yer alan etkinliğin içeriği ile ilgili oluşturulan anahtar kelimeler plan yapma, tahmin etme, kontrol etme, farklı stratejileri karşılaştırma, bir arada düşünme şeklindedir (Bkz. Tablo 3). Bu anahtar kelimeler ile soyutlama becerisini yordamak için oluşturulan bilişsel mekanizmaların anahtar kelimeleri karşılaştırıldığında söz konusu etkinliğin koordine etme kategorisi altında değerlendirilmesinin uygun olacağına karar verilmiştir. Etkinliklerin analizinde, herhangi bir etkinlik bir üst düzeyde eylem göstermişse sadece o düzeyde belirtilmesinin uygun olacağ 1 düşünülmüştür. Örneğin genelleme özelliğindeki bir etkinlik zaten içselleştirme kategorisi eylemlerini tamamlamaktadır. Dolayısıyla etkinlikler değerlendirilirken ve yorumlanırken kategorilerin kapsayıcılığı dikkate alınmıştır.

\section{Araştırmanın geçerliliği ve güvenirliliği}

Doküman incelemesi yapılan çalışmalarda herhangi bir uygulama yapılmadığı için, verilerin toplanması ve analizi aşamasında titiz çalışılması gerekmektedir. Bu tarz çalışmalarda öznelliğin baskın olması çalışmanın analizinin ne kadar geçerli ve güvenilir olduğu sorusunu ön plana çıkarmaktadır. Bu araştırmada da etkinliklerin betimsel analiz ile incelenmesinin söz konusu olması titiz bir çalışma yapılmasını gerektirmektedir. Bunun için öncelikle etkinliklerin 
künyelerinin çıkarılması aşamasında gözden kaçırılma durumları olmaması için, araştırmacı dışında farklı uzman kişilerden elde edilen verilerin doğruluğunun teyit edilmesi istenmiştir. Diğer yandan her sınıf düzeyinde rastgele belirlenen 20'şer etkinliğin soyutlama becerisi çerçevesinde analizlerinin başka bir uzman tarafından eş zamanlı olarak yapılması sağlanmıştır. Toplamda 80 etkinlik ile ilgili yapılan analizlerde kodlayıcılar arasındaki uyum, Miles ve Huberman (1994) uyum yüzdesi formülü ile hesaplanmış ve yaklaşık \%86 olarak bulunmuştur. Daha sonra uyumsuzluk yaşanan etkinlikler incelenmiş ve bu etkinliklerin hangi kategoriler altında değerlendirileceği ortak bir kararla sonuca bağlanmıştır. Ayrıca araştırmacı 157 etkinliğin analizini on gün ara verip tekrardan incelemiş ve etkinliklerin analizine son halini vermiştir.

\section{Bulgular}

Her sinıf düzeyinde tespit edilen etkinlikler soyutlamanın anahtar kelimeleri referans alınarak analiz edilmiş ve bu analizler her bir sınıf düzeyi için ayrı başlıklar altında verilmiştir. Daha sonra ise ortaokul etkinlikleri için genel değerlendirme hem tüm sınıflar hem de öğrenme alanları çerçevesinde sunulmuştur.

\section{Sinıf etkinlik analizleri}

Matematik dersi için 5. sınıfta sayılar ve işlemler, geometri ve ölçme ve veri işleme olmak üzere 3 öğrenme alanı yer almaktadır. Bu öğrenme alanları ile ilgili iki eğitim-öğretim dönemi boyunca 6 ünite ve 27 konu alanı belirlenmiştir. Bu konularla ilgili MEB'in önerdiği kaynak kitapta 45 etkinlik tespit edilmiştir. Bu etkinliklerin 29'u sayılar ve işlemler, 14'ü geometri ve ölçme, 2'si veri işleme öğrenme alanı ile ilgili etkinliklerdir. Etkinliklerin soyutlama becerisini temsil edebilme gücü incelenmiş ve elde edilen veriler Tablo 4'te sunulmuştur.

Tablo 4.

5. Sinıf Etkinlik Analizleri

\begin{tabular}{|c|c|c|c|c|c|}
\hline $\begin{array}{l}\text { Öğrenm } \\
\text { e } \\
\text { Alanları }\end{array}$ & İçselleştirme & Koordine etme & $\begin{array}{l}\text { Enkapsülasyo } \\
\mathrm{n}\end{array}$ & $\begin{array}{l}\text { Genellem } \\
\mathrm{e}\end{array}$ & $\begin{array}{l}\text { Tersine } \\
\text { Çevirm } \\
\text { e }\end{array}$ \\
\hline Sayılar & $\begin{array}{l}E_{5} 2, E_{5} 3, E_{5} 4, E_{5} 5, E_{5} 6 \\
E_{5} 7, E_{5} 8, E_{5} 9, E_{5} 10 \\
E_{5} 12, E_{5} 18, E_{5} 19, E_{5} 20 \\
E_{5} 21, E_{5} 24, E_{5} 25, E_{5} 26 \\
E_{5} 28, E_{5} 29\end{array}$ & $\begin{array}{l}E_{5} 1, E_{5} 11, E_{5} 13, E_{5} 15 \\
E_{5} 16, \\
E_{5} 17, E_{5} 22, E_{5} 23\end{array}$ & $E_{5} 14, E_{5} 27$ & - & - \\
\hline Cebir & - & - & - & - & - \\
\hline $\begin{array}{l}\text { Geometr } \\
\text { i ve } \\
\text { Ölçme }\end{array}$ & $\begin{array}{l}E_{5} 30, E_{5} 31, E_{5} 32 \\
E_{5} 33, E_{5} 34, E_{5} 37,\end{array}$ & $E_{5} 38, E_{5} 45$ & $E_{5} 36, E_{5} 39$ & $E_{5} 35$ & - \\
\hline $\begin{array}{l}\text { Veri } \\
\text { İşleme }\end{array}$ & $E_{5} 40, E_{5} 41, E_{5} 42, E_{5} 43$ & - & - & - & - \\
\hline Toplam & 30 & 10 & 4 & 1 & 0 \\
\hline
\end{tabular}

Tablo 4 incelendiğinde, 5. sinıfta yer alan toplam 45 etkinliğin 30'unun sadece ilgili kazanımı içselleştirmeye yönelik eylem içerdiği görülmüştür. Örneğin $E_{5} 7$ tahmin etme, strateji açılama ve karşılaştırma gibi eylemlerin ön planda olduğu bir etkinliği temsil etmektedir. Dolayısıyla bu etkinlik içselleştirme kategorisi çerçevesinde değerlendirilmiştir. Diğer yandan 10 etkinliğin koordine etme, 4 etkinliğin enkapsülasyon ve sadece 1 etkinliğin genelleme kategorisinde değerlendirildiği görülmektedir. Ayrıca etkinliklerin hiçbirinin tersine çevirme mekanizması ile ilgili eylemleri barındırmadığ 1 da tespit edilmiştir.

5. sınıfta sayılar ve işlemler öğrenme alanı ile ilgili toplamda 29 etkinlik vardır ve bu etkinliklerin 19'unun içselleştirme, 8'inin koordine etme ve 2'sinin enkapsülasyon kategorisinde yer aldığı görülmektedir (Tablo 4). Geometri ve ölçme öğrenme alanı ile ilgili etkinliklerin 9'unun içselleştirme, 2'şer tanesinin koordine etme ve enkapsülasyon kategorisinde olduğu fark edilmiştir. Genelleme kategorisinde değerlendirilen 1 etkinliğin ise yine bu öğrenme alanına ait 
olduğu tespit edilmiştir. Veri işleme öğrenme alanı ile ilgili etkinliklerin 2'si de içselleştirme kategorisinde değerlendirilmiştir.

Yapılan analizlerde etkinliklerin bazılarında $\left(E_{5} 4\right.$ ve $E_{5} 5$ gibi) öğrencilerin bilgiyi oluşturmalarını desteklemekten ziyade yönlendirmenin temele alındığ 1 fark edilmiştir. Ayrıca $E_{5} 8$ gibi bazı etkinliklerde ise öğrencilere kavramlar arası karşılaştırma yapmalarına firsat sağlanmış fakat öğrencinin bunu neden yapması gerektiği ile ilgili bir eylem içermediği görülmüştür. Söz konusu kavramın yapılandırılması için geliştirilen etkinliklerde bazı kavramların varlığı hissedilmiş fakat tam anlamı ile üzerinde durulmadan geçildiği fark edilmiştir. Örneğin $E_{5} 9$ 'da basamak değeri kavramının geliştirilmesi kısmen var ama bu kavram hesap makinası ile çarpmanın el ile yapılan çarpma işlemi ile kıyaslanmasının ötesine geçememiştir. Diğer yandan etkinliklerin genelinde soyutlamaya az ya da çok yer verildiği görülmüş fakat özellikle iyi yapılandırılmış olarak nitelendirilen etkinliklerde bile öğrencinin yaratıcılığını yarıda kesecek durumlarla karşılaşılmıştır. Örneğin $E_{5} 14$ bu durumu iyi şekilde örneklendiren bir etkinliktir.

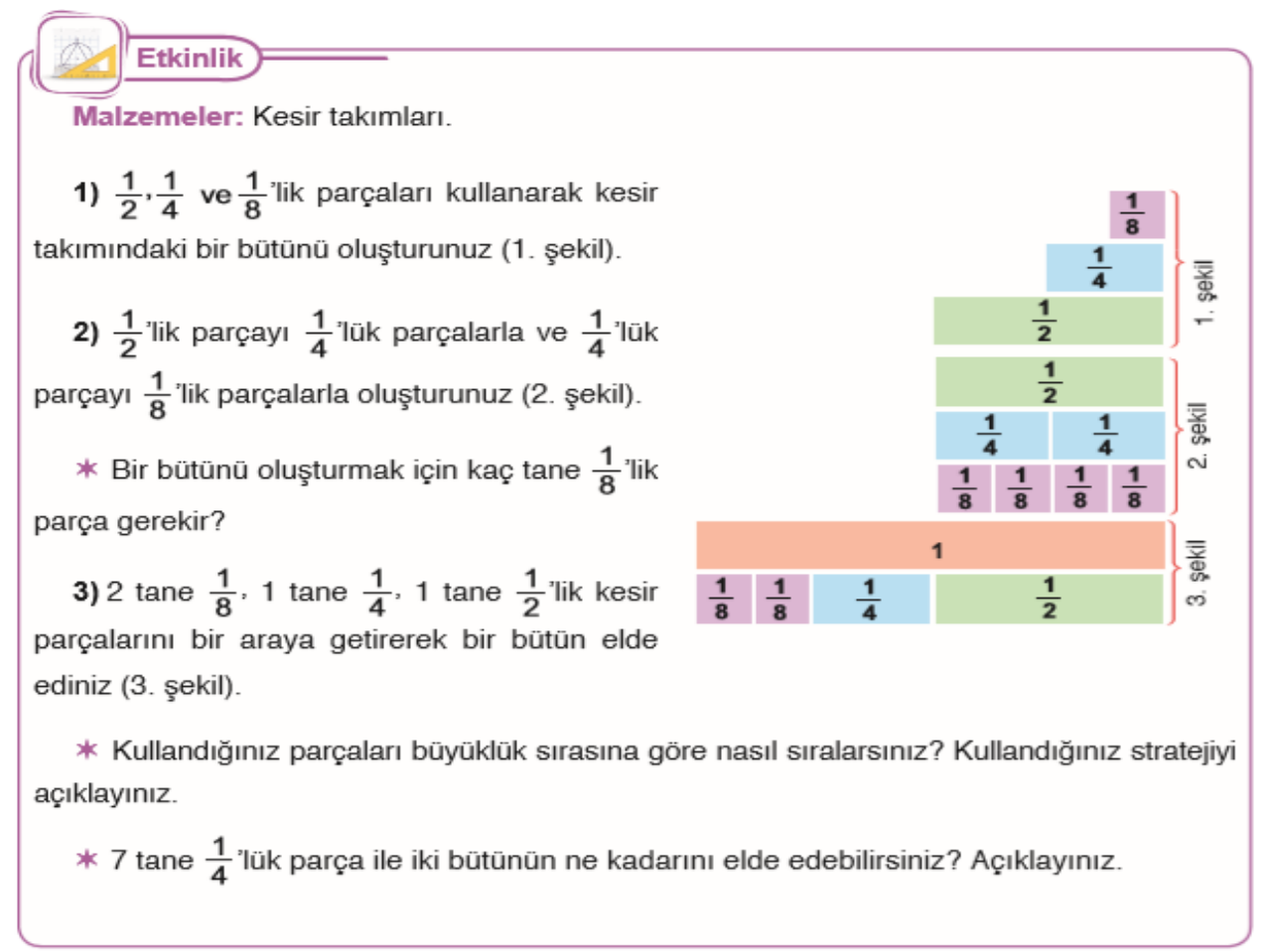

Şekil 2. Etkinlik temsili- $E_{5} 14$ (MEB, 2018, s. 25)

Şekil 2'de verilen etkinlikte kesir ile bütünün ilişkilendirilmesi söz konusudur. Parçalama, birleştirme, sıralama, bir arada düşünme, karşılaştırma, ilişkilendirme, yöntem kurma bu etkinliğin özetlendiği anahtar kelimelerdendir. Etkinliğin içselleştirme ve koordinasyon kategorilerini yansıttığı açıktır. Kesirli sayılardan hareketle tam sayıları parça-bütün ilişkisini kurarak oluşturması etkinliğin enkapsülasyon kategorisinde değerlendirilmesini gerekli kılmaktadır. Fakat etkinlikte genel bir yargıya varma gibi eylem söz konusu değildir. Örneğin birim kesirlerle bütün arasındaki ilişkinin ortaya çıkarılması söz konusu olsaydı genelleme olabilirdi. Üstelik bu tarz bir etkinlik bunun için oldukça elverişli görünmektedir. Etkinliklerde son aşamada genellikle pekiştirme ya da oluşturulan yapının sağlamlaştırılması için spesifik rakamlarla uygulama yapma söz konusudur. Bu durum ise öğrencilerin bilgiyi soyutlamasına engel teşkil etmektedir. 


\section{Sinıf etkinlik analizleri}

Ortaokul 6. sınıf matematik ders kitabında sayılar ve işlemler, cebir, geometri ve ölçme ve veri işleme öğrenme alanı ile ilgili 6 ünite ve 15 konu alanı yer almaktadır. Bu konularla ilgili toplamda 42 etkinlik tespit edilmiştir. Etkinliklerin 19 tanesi sayılar ve işlemler, 4'ü veri işleme ve 19'u geometri ve ölçme öğrenme alanı ile ilgili olup, cebir ile ilgili etkinliğin olmadığı tespit edilmiştir. Bu etkinliklerin soyutlama sürecine yönelik analizleri Tablo 5 'te sunulmuştur.

Tablo 5 .

6. Sinıf Etkinlik Analizleri

\begin{tabular}{|c|c|c|c|c|c|}
\hline $\begin{array}{l}\text { Öğrenme } \\
\text { Alanları }\end{array}$ & İçselleştirme & Koordine etme & Enkapsülasyon & Genelleme & $\begin{array}{l}\text { Tersine } \\
\text { Çevirme } \\
\end{array}$ \\
\hline Sayılar & $E_{6} 4, E_{6} 5, E_{6} 7$ & $\begin{array}{c}E_{6} 1, E_{6} 2, E_{6} 6, E_{6} 10 \\
E_{6} 19\end{array}$ & $\begin{array}{c}E_{6} 11, E_{6} 12, E_{6} 13 \\
E_{6} 16,\end{array}$ & $\begin{array}{c}E_{6} 3, E_{6} 8, E_{6} 9 \\
E_{6} 14, E_{6} 15, E_{6} 17 \\
E_{6} 18 \\
\end{array}$ & - \\
\hline Cebir & - & - & - & - & - \\
\hline $\begin{array}{l}\text { Geometri ve } \\
\text { Ölçme }\end{array}$ & $E_{6} 28, E_{6} 29, E_{6} 39$ & $\begin{array}{l}E_{6} 26, E_{6} 27, E_{6} 34, \\
E_{6} 36, E_{6} 41, E_{6} 42\end{array}$ & $E_{6} 30, E_{6} 35, E_{6} 37$ & $\begin{array}{l}E_{6} 24, E_{6} 31, E_{6} 32 \\
E_{6} 33, E_{6} 38, E_{6} 40\end{array}$ & - \\
\hline Veri İşleme & $E_{6} 23$ & $E_{6} 21$ & $E_{6} 20, E_{6} 22$ & - & - \\
\hline Toplam & 7 & 12 & 9 & 13 & 0 \\
\hline
\end{tabular}

Tablo 5'e göre etkinliklerin 7'sinin içselleştirme, 12'sinin koordine etme, 9'unun enkapsülasyon ve 13'ünün genelleme ile ilgili bilişsel mekanizmaları desteklediği bulunmuştur. Hiçbir etkinliğin tersine çevirme ile ilgili bilişsel eylemi barındırmadığı görülmüştür. Ayrıca $E_{6} 25$ numaralı etkinlik ise sadece yönlendirmeden ibaret olduğu için herhangi bir kategori altında değerlendirilmemiştir.

Öğrenme alanlarına bakılarak inceleme yapılacak olursa, sayılar ve işlemler öğrenme alanı ile ilgili etkinliklerin 4 kategoride de temsil edildiği görülmektedir. Örneğin içselleştirmede $E_{6} 4, E_{6} 5, E_{6} 7$; koordine etmede $E_{6} 1, E_{6} 2, E_{6} 6, E_{6} 10, E_{6} 19$; enkapsülasyonda $E_{6} 11, E_{6} 12, E_{6} 13$, $E_{6} 16$; genellemede $E_{6} 3, E_{6} 8, E_{6} 9, E_{6} 14, E_{6} 15, E_{6} 17, E_{6} 18$ numaralı etkinliklerin yer aldı ${ }_{1}$ görülmektedir. Benzer şekilde geometri ve ölçme öğrenme alanına ait etkinliklerin de 4 ayrı kategoriye yayıldığ 1 tespit edilmiştir. Ayrıca veri işleme öğrenme alanında yer alan 4 etkinliğin ise ilk üç kategoride temsil edildiği fark edilmiştir.

Ortaokul etkinlikleri arasında soyutlamaya en yakın etkinliklerin 6. sınıfa ait olduğu görülmüştür. Fakat etkinliklerin genelinin günlük hayattan uzak sadece matematiksel kavramlarla oluşturulduğu fark edilmiştir. Ayrıca baştan sona öğrenciyi yönlendiren etkinliklerin de az sayıda olmadığı görülmüş ve dikkat çekmiştir. Diğer yandan bu sınıf düzeyindeki etkinliklerde özellikle 6. ünitede kullanışlılık ilkesinin ön planda olduğu her etkinlik için fark edilmiştir. Örneğin $E_{6} 40$ numaralı etkinlik hem birimlerin kullanışlılığ etmektedir. 


\section{Etkinlik Kaç Santimetreküp?}

Araọ ve Gereọler: santimetrekarelik kağtt, makas, bant, santimetrekūp

- Santimetrekarelik kağıdımızdan $12^{\prime}$ ye 12 boyutlarında bir kare elde edelim. Bu karenin dört köșesinden șekildeki gibi birer santimetrekare kesip atalım.

- Karemizden kalan kısımlan yukan kıvınp kōșelerini bant ile yapıştırarak ayritlannın uzunluğu $10 \mathrm{~cm}, 10 \mathrm{~cm}$ ve $1 \mathrm{~cm}$ olan bir prizma elde edelim.

$\rightarrow$ Olușturduğunuz prizma, kaç tane santimetrekūp ile dolar?

- Prizmamızın hacmini bulalım ve sembolle gósterelim.

$\rightarrow 10 \mathrm{~cm}, 10 \mathrm{~cm}$ ve $10 \mathrm{~cm}$ boyutlannda bir küp elde etmek için hazırladığınız prizmadan kaç kat koymak gerekir? Olușacak küpün hacmi kaç $\mathrm{cm}^{3}$ olur?

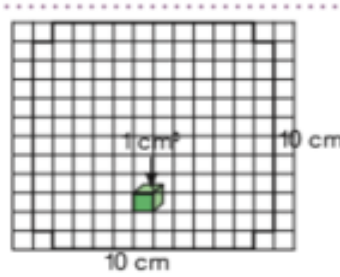

- Küpün ayrtiannın uzunluklarını dm birimine dónüștürelim ve hacminin kaç dm³ olduğunu bulalım.

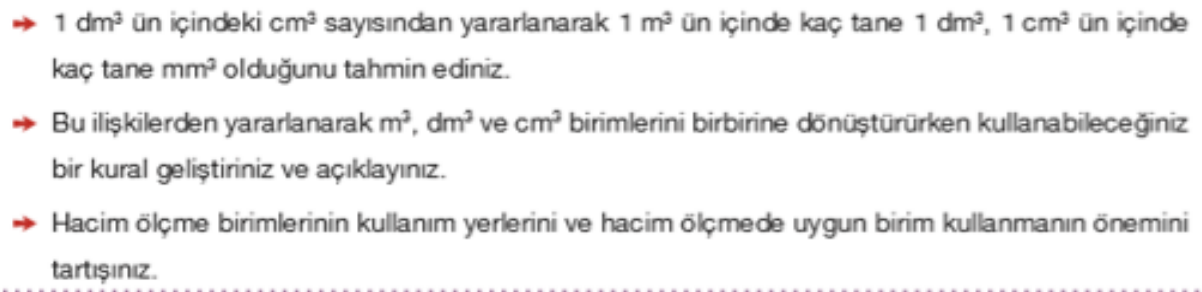

Şekil 3. Etkinlik temsili- $E_{6} 40$ (MEB, 2018, s. 150)

Şekil 3'te yer alan etkinlik soyutlama becerisi barındıran bir etkinliktir. Bu etkinlikteki temel fikir hacim kavramının öğrenci zihninde oluşturulması ile ilgilidir. Öncelikle öğrencilerin bilgi sahibi oldukları iki boyutlu şekillerden hareket edildiği görülmüştür. Prizma ile küp arasındaki ilişkiden hareketle hacim kavramını oluşturmak istemektedir. Ardından birimlere dikkat çekmekte ve uygun kullanımın önemini tartışmalarını istemektedir. $\mathrm{Bu}$ özellikler yukarıdaki etkinliği soyutlama becerisini kullanmayı gerektiren etkinlik yapmaktadır.

\section{Sinıf etkinlik analizleri}

Ortaokul 7. sınıf matematik ders kitabında sayılar ve işlemler, cebir, geometri ve ölçme ve veri işleme olmak üzere 4 öğrenme alanına ait toplamda 47 etkinlik tespit edilmiştir. $\mathrm{Bu}$ etkinliklerin 24'ü sayılar ve işlemler, 6'sı cebir, 13'ü geometri ve ölçme, 4 tanesi ise veri işleme öğrenme alanına ait olduğu görülmektedir. Bu etkinliklerin soyutlama sürecine yönelik analizleri şu şekildedir.

Tablo 6.

7. Sinıf Etkinlik Analizleri

\begin{tabular}{|c|c|c|c|c|c|}
\hline $\begin{array}{l}\text { Öğrenme } \\
\text { Alanları }\end{array}$ & İçselleştirme & Koordine etme & Enkapsülasyon & Genelleme & $\begin{array}{l}\text { Tersine } \\
\text { Çevirme }\end{array}$ \\
\hline Sayılar & $\begin{array}{l}E_{7} 2, E_{7} 3, E_{7} 4, E_{7} 6 \\
E_{7} 7, E_{7} 8, E_{7} 13, E_{7} 14 \\
E_{7} 21, E_{7} 26, E_{7} 27 \\
E_{7} 29, E_{7} 30\end{array}$ & $\begin{array}{c}E_{7} 1, E_{7} 9, E_{7} 11 \\
E_{7} 20, E_{7} 24, E_{7} 25\end{array}$ & $E_{7} 12, E_{7} 22, E_{7} 23$ & & - \\
\hline Cebir & $E_{7} 16, E_{7} 18, E_{7} 19$ & $E_{7} 15, E_{7} 20$ & & $E_{7} 17$ & - \\
\hline $\begin{array}{l}\text { Geometri ve } \\
\text { Ölçme }\end{array}$ & $\begin{array}{l}E_{7} 31, E_{7} 32, E_{7} 40 \\
E_{7} 41\end{array}$ & $E_{7} 33, E_{7} 34, E_{7} 39$ & $\begin{array}{l}E_{7} 35, E_{7} 36, E_{7} 37 \\
E_{7} 38\end{array}$ & & - \\
\hline Veri İşleme & $E_{7} 46$ & $\begin{array}{l}E_{7} 42, E_{7} 43, E_{7} 44 \\
E_{7} 45, E_{7} 47\end{array}$ & & & - \\
\hline Toplam & 21 & 15 & 7 & 1 & 0 \\
\hline
\end{tabular}


Tablo 6'da 21 etkinliğin içselleştirme, 15 etkinliğin koordine etme, 7 etkinliğin enkapsülasyon ve sadece 1 etkinliğin genelleme kategorisinde değerlendirildiği görülmektedir. Ayrıca tersine çevirme ile ilgili eylemlere hiçbir etkinlikte rastlanmamıştır. Diğer yandan 3 etkinlik $\left(E_{7} 5, E_{7} 10, E_{7} 28\right)$ yönlendirmelerle ilerleyen oldukça basit eylemleri içeren etkinlikler olduğundan herhangi bir kategori altında değerlendirilmemiştir. Etkinliklerin birçoğunda olay örgüsünün olmadığ genellikle sıralı işlemlerin olduğu tespit edilmiştir. Örneğin $E_{7} 5$ numaralı etkinlikte öğrencilere üslü sayılarla ilgili hemen öncesinde öğrendiklerine benzer siradan işlemlerin içerildiği uygulamalar yapmaları istenmiştir. Dolayısıyla bu tür etkinliklerin soyutlamanın bilişsel mekanizmalarını yansıtabilme gücünde olduğu düşünülmemiştir.

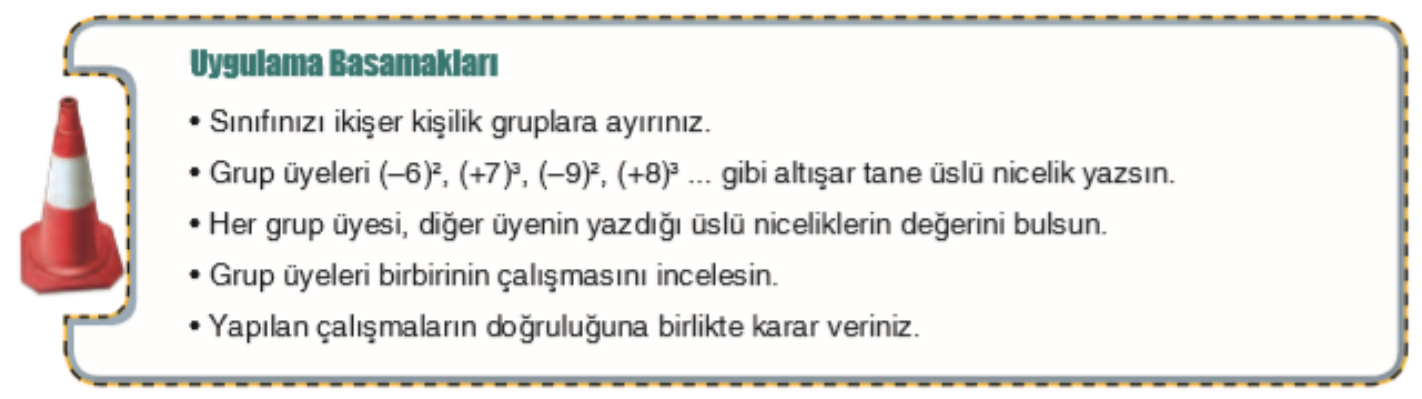

Şekil 4. Etkinlik temsili- $\boldsymbol{E}_{\mathbf{7}} \mathbf{5}$ (MEB, 2018, s. 41)

Sayılar ve işlemler, geometri ve ölçme öğrenme alanları ile ilgili etkinliklerin ilk üç kategoride kümelendiği fark edilmiștir. Cebir öğrenme alanında hazırlanan etkinliklerin ise 4 farklı kategoride de yer aldığı tespit dilmiştir. Burada dikkat çeken bir husus aynı öğrenme alanında olan etkinliklerin birbirine benzer olmasıdır $\left(E_{7} 24\right.$ ve $E_{7} 25$ gibi). Örneğin doğru orantı ile ters orantı etkinlikleri benzer şekilde kurgulanmış ve değişen tek şey doğru ve ters kavramları olmuştur.

Etkinliklerin analizlerinde öğrencilerin farkındalıklarını ortaya çıkarmak yerine onlara hazır bilgiyi sunup bunlar üzerinden hareket ettirmek sıklıkla karşılaşılan bir durum olmuştur. $\mathrm{Bu}$ durum soyutlamanın önündeki en önemli engellerden biridir. Örneğin $E_{7} 36$ numaralı etkinlikte anlatılmak istenen şey açıktır.

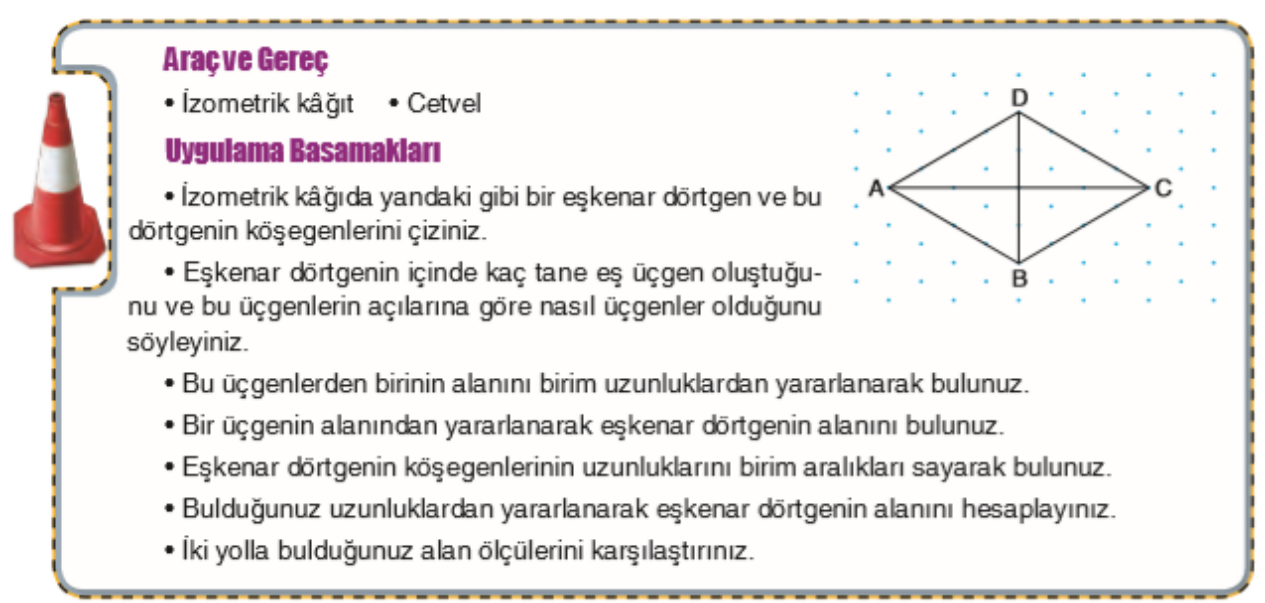

Şekil 5. Etkinlik temsili-E 36 (MEB, 2018, s. 205)

Şekil 5'te yer alan etkinlikte öğrencilerden eşkenar dörtgenin alanını bulmaları istenmiştir. Burada öğrenci kendi düşüncesi ile üçgenin alanından hareketle eşkenar dörtgenin alanını bulabileceğini fark edebilir. Fakat buna firsat vermeden öğrenci yönlendirilmiştir. Bu durum öğrencinin bilgiyi kendisinin oluşturmasının yani soyutlamasının önüne geçmektedir. 
Benzer durumla farklı etkinliklerde de karşılaşılmaktadır. Diğer yandan bazı etkinliklerde ise tek bir örnek durum üzerinden öğrencilerin genelleme yapmalarının istendiği fark edilmiştir. Örneğin $E_{7} 9$ numaralı etkinlikte öğrencilerden rasyonel sayılarda birleşme özelliğinin olup olmadığını bulmaları istenmektedir (Şekil 6). Burada genel bir ifadeye ulaşmak söz konusudur fakat bunu tek bir örnek üzerinde yapmak,öğrenci için ilerleyen zamanlarda problem yaratan bir durum haline gelebilir. Özellikle ispat becerisinde öğrencilerin yanlış genellemeler yapmalarını destekleyebilir.

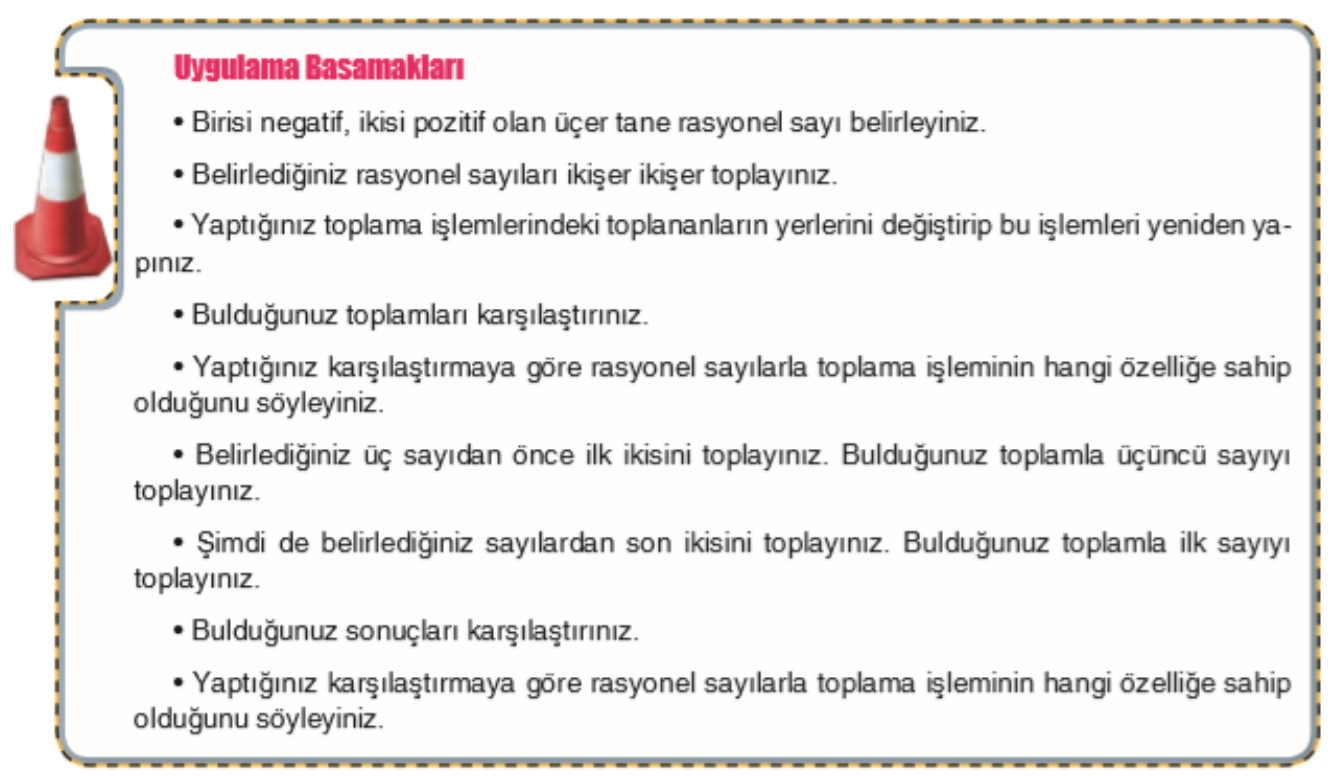

Şekil 6. Etkinlik temsili- $E_{7} 9$ (MEB, 2018, s. 67)

\section{Sınıf etkinlik analizleri}

Ortaokul 8. sınıf matematik ders kitabında tüm öğrenme alanları yer almaktadır. Sayılar ve işlemler ve cebir öğrenme alanlarından 5'er tane, geometri ve ölçmeden 12, olasılıktan ise 1 tane olmak üzere toplamda 23 etkinlik tespit edilmiştir. Veri işleme öğrenme alanı ile ilgili etkinliğin olmaması da dikkat çekmiştir. Bu etkinliklerin soyutlama çerçevesinde analizleri yapılmış ve elde edilen bulgular Tablo 7'de özetlenmiştir.

Tablo 7.

8. Sinıf Etkinlik Analizleri

\begin{tabular}{|c|c|c|c|c|c|}
\hline $\begin{array}{l}\text { Öğrenme } \\
\text { Alanları }\end{array}$ & İçselleştirme & Koordine etme & Enkapsülasyon & Genelleme & $\begin{array}{l}\text { Tersine } \\
\text { Çevirme }\end{array}$ \\
\hline Say1lar & $E_{8} 4, E_{8} 5$ & & $E_{8} 1, E_{8} 6$ & $E_{8} 2, E_{8} 3$ & - \\
\hline Cebir & $E_{8} 7, E_{8} 10, E_{8} 11$ & $E_{8} 8, E_{8} 9$ & & & - \\
\hline $\begin{array}{l}\text { Geometri ve } \\
\text { Ölçme }\end{array}$ & $E_{8} 19, E_{8} 21, E_{8} 22$ & $E_{8} 20$ & $\begin{array}{l}E_{8} 14, E_{8} 15 \\
E_{8} 16, E_{8} 23\end{array}$ & $E_{8} 12, E_{8} 13, E_{8} 18$ & - \\
\hline Veri İşleme & - & - & - & - & - \\
\hline Toplam & 8 & 3 & 6 & 5 & 0 \\
\hline
\end{tabular}

Tablo 7'de yer alan bulgulara göre, 8 etkinliğin içselleştirme, 3 etkinliğin koordine etme, 6 etkinliğin enkapsülasyon ve 5 etkinliğin genelleme kategorisinde değerlendirildiği görülmektedir. Geometri öğrenme alanı ile ilgili 1 etkinlik ise $\left(E_{8} 17\right)$ soyutlama eylemleri açısından tanımlanamadığı için kategori edilememiştir. Burada dikkat çeken nokta enkapsülasyon aşamasında tüm öğrenme alanlarından en az bir tane etkinliğin yer almasıdır. Diğer önemli husus ise geometri ve ölçme öğrenme alanı ile ilgili etkinliklerin 4 farklı kategoride de temsil edilebilmesidir. 
Analizler sırasında bazı etkinliklerde öğrencilerden bir özel durumla genel bir ifadeye ulaşmalarının istendiği tespit edilmiştir. Örneğin $E_{8} 14$ numaralı etkinlikte öğrencilerin öncelikle bir üçgen çizimi yapması sağlanmış daha sonra öğrencilerden üçgen çiziminde kenar uzunlukları hakkında yorum yapmaları ve genel bir ifadeye ulaşmaları istenmiştir (Şekil 7). Sadece bir özel durumla yapılan genel kanıya varma işlemi, soyutlama eylemlerinden olan genelleme ile aynı şey değildir. Öğrenci farklı ölçülerdeki üçgenlerin, bu kanıyı sağlanıp sağlanmadığını kontrol etmediği sürece, aynı genel kanıya varamayabilir. Yani bir örnekle yapılan genel kanıya varma işlemi, soyutlama için genelleme yapmaya engel teşkil eden bir durumdur. Dolayısıyla Şekil 7'de yer alan etkinlik sentezleme eyleminden ileri gidememiş ve enkapsülasyon kategorisi altında değerlendirilmiştir.

\section{Etkinlik}

Araç ve Gereçler: A4 kâğıdı, pergel, cervel.

1) A4 kâğıdına 1. şekildeki gibi belirli bir uzunlukta bir $[A B]$ çiziniz.

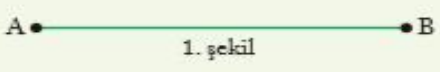

2) Pergelin uçlanı arasındaki mesafeyi belirli bir ö1çüde açarak 2. şekildeki gibi A merkezli bir yay parçası çiziniz.

3) Pergelin uçları arasındaki mesafeyi değiştirerek 2 . aşamada çizdiğiniz yayı kesen 3 . şekildeki gibi B merkezli bir yay parçası çiziniz.

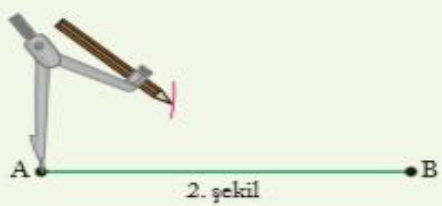

4) Yayların kesim noktasını $C$ ile göstererek 4 . şekildeki gibi $[\mathrm{AC}]$ ve $[\mathrm{BC}]$ 'nı çiziniz.

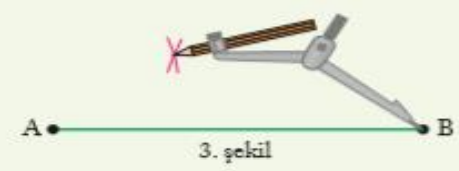

5) Bir üçgenin çizilebilmesi için kenar uzunluklarının bilinmesinin yeterli olup olmadığına arkadaşlarınızla konuşarak karar veriniz.

Şekil 7. Etkinlik temsili- $E_{8} 14$ (MEB, 2018, s. 82)

\section{Etkinliklerin genel analizi}

$\mathrm{Bu}$ kısımda etkinliklerin hem sınıf hem de öğrenme alanı bazında karşılaştırmaları yapılmıştır. Etkinliklerin hangi sıklıkta ve hangi kategoriler altında değerlendirildiği yüzdelik dilimleri (yaklaşık değer) ile birlikte aşağıdaki tabloda verilmiştir.

Tablo 8.

Ortaokul Matematik Etkinlik Genel Analizleri

\begin{tabular}{llllllll}
\hline & İçselleştirme & $\begin{array}{l}\text { Koordine } \\
\text { Etme }\end{array}$ & Enkapsülasyon & Genelleme & $\begin{array}{l}\text { Tersine } \\
\text { Çevirme }\end{array}$ & $\begin{array}{l}\text { Kategori } \\
\text { edilemeyen }\end{array}$ & Toplam \\
\hline 5. Sinıf & $30(\% 67)$ & $10(\% 22)$ & $4(\% 9)$ & $1(\% 2)$ & 0 & 0 & $\mathbf{4 5}$ \\
\hline 6. Sinıf & $7(\% 17)$ & $12(\% 29)$ & $9(\% 21)$ & $13(\% 31)$ & 0 & $1(\% 2)$ & $\mathbf{4 2}$ \\
\hline 7. Sinıf & $21(\% 45)$ & $15(\% 32)$ & $7(\% 15)$ & $1(\% 2)$ & 0 & $3(\% 6)$ & $\mathbf{4 7}$ \\
\hline 8. Sinıf & $8(\% 35)$ & $3(\% 13)$ & $6(\% 26)$ & $5(\% 22)$ & 0 & $1(\% 4)$ & $\mathbf{2 3}$ \\
\hline
\end{tabular}


Tablo 8'e göre 5., 7. ve 8. sinıflarda en fazla içselleştirme ile ilgili etkinliklere yer verilirken 5. ve 7. sinıfta yer alan etkinliklerin en az genelleme kategorisinde değerlendirildiği fark edilmiştir. 6. sınıf etkinlikleri ise diğer sınıfların aksine en az içselleştirme ve en fazla genelleme içeren etkinlikler olmuşlardır. Ayrıca sınıf düzeylerinde hiçbir etkinliğin tersine çevirme ile ilgili eylemleri barındırmadığı da fark edilmiştir. Burada önemli olan husus etkinliklerin soyutlama konusunda konu alanlarına nasıl dağıldığıdır. Ortaokul matematik ders kitaplarında yer alan etkinlikler öğrenme alanları bazında soyutlamanın bilişsel mekanizmaları açısından ele alınmış ve elde edilen sınıflamalar Tablo 9'da sunulmuştur:

Tablo 9.

Öğrenme Alanlarına Göre Soyutlama Eylemleri

\begin{tabular}{|c|c|c|c|c|c|}
\hline & Sayılar ve İşlemler & Cebir & $\begin{array}{l}\text { Geometri } \\
\text { Ölçme }\end{array}$ & Veri İşleme & Olasılık \\
\hline $\begin{array}{l}5 . \\
\text { Sinif }\end{array}$ & $\begin{array}{l}\text {-İçselleştirme } \\
\text {-Koordine etme } \\
\text {-Enkapsülasyon }\end{array}$ & - & $\begin{array}{l}\text {-İçselleştirme } \\
\text {-Koordine etme } \\
\text {-Enkapsülasyon } \\
\text {-Genelleme }\end{array}$ & -İçselleştirme & - \\
\hline $\begin{array}{l}6 . \\
\text { Sinıf }\end{array}$ & $\begin{array}{l}\text {-İçselleştirme } \\
\text {-Koordine etme } \\
\text {-Enkapsülasyon } \\
\text {-Genelleme }\end{array}$ & Etkinlik Yok & $\begin{array}{l}\text {-İçselleştirme } \\
\text {-Koordine etme } \\
\text {-Enkapsülasyon } \\
\text {-Genelleme }\end{array}$ & $\begin{array}{l}\text {-İçselleştirme } \\
\text {-Koordine etme } \\
\text {-Enkapsülasyon }\end{array}$ & - \\
\hline $\begin{array}{l}7 . \\
\text { Sinıf }\end{array}$ & $\begin{array}{l}\text {-İçselleştirme } \\
\text {-Koordine etme } \\
\text {-Enkapsülasyon }\end{array}$ & $\begin{array}{l}\text {-İçselleştirme } \\
\text {-Koordine etme } \\
\text {-Enkapsülasyon } \\
\text {-Genelleme }\end{array}$ & $\begin{array}{l}\text {-İçselleştirme } \\
\text {-Koordine etme } \\
\text {-Enkapsülasyon }\end{array}$ & $\begin{array}{l}\text {-İçselleştirme } \\
\text {-Koordine etme } \\
\text {-Enkapsülasyon }\end{array}$ & - \\
\hline $\begin{array}{l}8 . \\
\text { Sinıf }\end{array}$ & $\begin{array}{l}\text {-İçselleştirme } \\
\text {-Enkapsülasyon } \\
\text {-Genelleme }\end{array}$ & $\begin{array}{l}\text {-İçselleştirme } \\
\text {-Koordine etme }\end{array}$ & $\begin{array}{l}\text {-İçselleştirme } \\
\text {-Koordine etme } \\
\text {-Enkapsülasyon } \\
\text {-Genelleme }\end{array}$ & Etkinlik Yok & -Enkapsülasyon \\
\hline
\end{tabular}

Tablo 9'a göre, her sınıf düzeyinde içselleştirmeden genellemeye kadar etkinliklerin yer aldığı ifade edilebilir fakat öğrenme alanlarıkendi içinde değerlendirilecek olursa, genelleme türünde etkinliklerin her öğrenme alanında yer almadığı ifade edilebilir. Örneğin 7. sınıfta olasılık hariç diğer öğrenme alanlarından konular yer almaktadır. Fakat sadece cebir öğrenme alanı ile ilgili öğrencilerin genelleme yapmalarına firsat tanıyan etkinliklere yer verildiği görülmektedir. Ayrıca müfredatta öğrenme alanları ile ilgili konular yer almasına rağmen o konuyla ilgili etkinliklerin olmadığ 1 da fark edilmiştir. Örneğin 6 . sınıfta cebirle ilgili, 8. sınıfta ise veri işleme ile ilgili konular yer alırken etkinliklerin olmadığ tespit edilmiştir.

\section{Tartışma ve Sonuç}

Ders kitapları eğitim reformlarına öncülük eden öğretim materyallerindendir (Johansson, 2003). Dolayısıyla eğitimde değişimi ve yenilenmeyi hedef alan ülkemiz politikası için ders materyallerinin geliştirilmesi önemli bir yer tutmaktadır. Bu çalışmada ortaokul matematik etkinliklerinin soyutlama becerisini yansıtma düzeyleri incelenmiştir. Bu amaç çerçevesinde her sınıf öğrenme alanları bazında ayrı ayrı ele alınmıştır. Ortaokul matematik ders kitabında tayin edilen toplam 157 etkinliğin 20'sinin (\%31) genelleme kategorisinde değerlendirildiği görülmektedir. Özellikle 5. ve 7. sinıfta birer etkinlik ile genelleme özelliği gösteren etkinliklerin oldukça az sayıda olduğu dikkat çekmektedir. 5. sınıf soyutlama becerisi açısından yaş sınırı olarak uygun bulunmayabilir fakat Piaget (1970) soyutlama becerisinin 11 yaş ve üzeri çocuklarda gelişiminin belirgin olduğunu ancak anaokulu çağındaki çocuklarda bile gözlenebileceğini ifade etmektedir (akt. Ferrari, 2003). Üstelik 7. sınıf soyutlama becerisinin en etkili kullanılabileceği matematik konularını ihtiva etmesine rağmen bu düzeyde soyutlama etkinliklerinin yeterli sayıda olmaması bir eksiklik olarak nitelendirilebilir. Soyutlama becerisinde yaş düzeyi kadar konu da önemlidir. Bazı konular bu beceriye geniş imkânlar verir. Mesela 5. sınıf düzeyinde yer alan basamak değeri kavramı öğrencilerin eski bilgilerinden hareketle rahatlıkla anlam oluşturabilecekleri bir kavram iken hesap makinası ile yapılan çarpma 
işleminin elle yapılan çarpmaya göre kıyaslanması şeklinde verildiği tespit edilmiştir. Bu etkinlik genelleme düzeyinde yapılandırılması mümkün iken içselleştirme etkinliği olarak kategori edilmiştir.

Elde edilen bulgular her sınıf düzeyinde (bazı etkinlikler kategori edilmesede) soyutlama becerisine yönelik eylemlerin en aziçselleştirme düzeyinde var olduğunu göstermektedir. Bazı etkinliklerin daha ileri matematiksel soyutlamayı destekleyici şekilde kurgulanabilmesine karşın eksik ya da yarım bırakılması dikkat çekmiştir. Örneğin $E_{5} 35, E_{5} 38$ ve $E_{5} 45$ numaralı etkinlikler hem konusu hem de yapısı bakımından öğrencilerin rahatlıkla genelleme yapacağı etkinlikler iken yarıda kesilmiş eylemleri içermektedir. Üstelik bu durumla her sınıf düzeyinde karşılaşılmıştır. Yani kavramlar arasında ilişki kurulması sağlanmış fakat öğrencilerin bu ilişkiyi neden kurmaları gerektiğine yönelik eylemlere yer verilmediği fark edilmiştir. Örneğin, etkinlikte herhangi bir geometrik şeklin alan hesaplamasında, şeklin kenar uzunluğu ile hesaplanan alan ölçüsü arasında bir ilişki olup olmadığı sorgulanmış ama bu ilişkilendirmenin neden yapıldığı ile ilgili herhangi bir görev yer almadığı görülmüştür. Yarım bırakılan eylemler konunun anlaşılmasının bile önüne geçebilir. Ayrıca 6. ve 7. sınıfta aynı konuya ait benzer etkinlikler tespit edilmiştir. 6. sınıfta yer alan etkinlik soyutlamaya imkân veren bir etkinlik iken 7 . sınıftaki etkinlik içselleştirme etkinliği olarak kalmıştır. Seviye yükselmesine, konular aynı olmasına ve etkinlikler benzer şekilde yapılandırılmasına rağmen alt sınıfta yer alan etkinliğin daha iyi oluşturulması etkinlik hazırlamada gösterilen özeni ifade etmektedir. Matematik müfredatı sarmal yapıda hazırlanmaktadır. Dolayısıyla Hong, Choi, Runnalls ve Hwang (2018) ve Collopy (2003) tarafından yapılan çalışmalarda da olduğu gibi etkinliklerin hazırlanmasında sınıf düzeylerinin kendi içerisinde bütünlük göstermesi yeterli değildir, aynı zamanda sınıflar arası armoni de önemlidir.

Etkinliklerin bazılarında $\left(E_{7} 9, E_{8} 14, E_{8} 15, E_{8} 16\right.$ gibi) öğrencilere bir örnek durum üzerinden hareket ederek genelleme yapmaları istendiği görülmüştür. Bu durum ispat becerisini de yanlış yönde etkileyebilir. Tek doğru durum ile cevabın doğruluğundan emin olunması ispat sürecindeki yanlış algılardan biridir. Nitekim Harel ve Sowder'e (1998) göre bir ya da birkaç doğrunun verilen ifadeyi doğrulamak için yeterli olacağı düşüncesini öğrencilere kazandırmak, aslında onlarda oluşacak kavram yanılgısının başlıca sebebidir. Dolayısıyla kavram yanılgısını tetikleyen etkinlikler ile soyutlama becerisinin kazandırılmasının beklenmesi doğru değildir.

Matematiksel kavramların öğrencinin tanıdık olduğu günlük hayatla iç içe verilmesi soyutlama sürecinin etkili bir şekilde yönetilmesinde önemli yer tutmaktadır. Bu çalışmada etkinlikler soyutlama becerisini temsil edebilme düzeyine göre incelendiğinden araştırmacının bir öngörüsü olacak şekilde günlük hayatla etkinliklerin ilişki düzeyi de dikkate alınmıştır. Elde edilen verilere göre etkinliklerin genellikle günlük hayattan kopuk sadece ilgili konunun kavramları ile şekillendirildiği fark edilmiştir. Örneğin 8.sınıfta bulunan $E_{8} 8$ numaralı etkinliğin matematiksel kavramlarla zenginleştirilip günlük yaşamla bağdaştırılması ile soyutlama sürecine daha çok katk1 sağlayacağ1 düşünülmüştür. Gerçekçi durumlarla matematiksel kavramların yapılandırılması ile öğrencilerin söz konusu kavramları öğrenmesi, matematiksel başarı elde etmesi ve bunu kalıcı hale getirmesi daha mümkün görülmektedir (Altaylı, 2018; Memnun Sezgin ve Altun, 2012; Karataş ve Güven, 2010).

Etkinlik analizlerinde dikkat çeken bir husus ise, öğrencilerin bazı etkinliklerde hazır bilgileri kullanmalarının teşvik edilmesidir. Oysaki soyutlama becerisi önündeki en büyük engellerden biri de budur. Soyutlama becerisinde önemli olan anlam oluşturmadır ve bu ancak bireyin kendi zihninde gerçekleşen bir eylemdir. Kavramın soyutlanması bilginin öğrenci tarafından oluşturulması ile mümkün olmaktadır. Dolayısıyla hazır bilgilerin öğrencilere sunulması bu eylemin gerçekleşmesi önünde başta konulmuş bir engeldir. Diğer yandan bazı etkinliklerde öğrencilerin sürekli yönlendirildiği fark edilmiştir. Bu da soyutlama becerisi için hazır bilginin yarattığ duruma benzer bir engeli teşkil etmektedir. Etkinliklerle ulaşılmak istenen yapı en başından belirgin ve bu yapıyı elde etmeleri için öğrencilere yöneltilen adımlar mevcuttur. Üstelik bu etkinliklerin öğrencilerin yaratıcılığına firsat veren özellikte olduğu tespit edilmiştir. Fakat yönlendirmeler amaçlarından saparak öğrencilerin yaratıcılığını ortaya koymalarına engel olmaktadır. Yaratıcılık ise soyutlama ile dinamik bir ilişki içerisinde olan kavramdır. Üstelik 
bireyin derin düşünmesini destekleyen en önemli faktörlerden biridir (Reys, Lindquist, Lambdin ve Smith, 2002). Williams (2002) yeni matematiksel kavramların oluşturulmasında yaratıcılığın oldukça etkili bir faktör olduğunu ifade etmiştir. Diğer taraftan Welling (2007) soyutlamayı yaratıcılık teorisinde yaratıcı bilişsel eylemlerin bir bileşeni olarak ifade etmiş ve yaratıcılık için temel bir eylem olduğunu söylemiştir.

Bu çalışmada ayrıca soyutlama becerisi öğrenme alanları çerçevesinde de incelenmiştir. Sayılar ve işlemler ve geometri ve ölçme öğrenme alanlarında hazırlanan etkinliklerin diğer öğrenme alanlarına nazaran soyutlama çerçevesinde daha iyi şekilde kurgulandıkları fark edilmiştir. Mitchelmore ve White'a (2007) göre soyutlama süreçlerinin incelenmesinde seçilecek konunun etkisi büyüktür. Soyutlama ile ilgilenen araştırmacıların çalışmaları incelendiğinde ise genellikle cebir konularını tercih ettikleri görülmüştür (örn. Kabael, 2011; Murray, 2002; Özmantar, 2004; Tzirias, 2011). Elde edilen bulgulara bakılacak olursa cebir konusunda hazırlanan etkinliklerde soyutlama eylemlerine yeterince yer verilmediği ifade edilebilir.

Sonuç olarak ders kitaplarında yer alan etkinliklerin soyutlama eylemlerini daha iyi şekilde yansıtma gücü ve imkanı varken, etkinliklerin soyutlama becerisi çerçevesinde yeterli şekilde kurgulanmadığ1 söylenebilir. Üstelik soyutlama ile ilgili kategorilerin ihtiva ettiği eylemlere bakılacak olursa, bu eylemler sadece soyutlama becerisi altında değil, ilişkilendirme, ispat yapma, tahmin etme, problem kurma gibi farklı matematiksel becerileri de temsil eden eylemlerdir. Dolayısıyla elde edilen verilere göre eylemlerin genel olarak yeterli sayıda temsil edilemediğini ortaya koymak yanlış olmayacaktır. Oysaki matematik müfredatında bu becerilerin önemine ayrı ayrı değinilmiş ve öğretimin öğrenci merkezli öğretmen rehberli olmak üzere yapılandırmacı çerçeveye uygun şekilde tasarlanmasının gereği ifade edilmiştir. Fakat ders kitaplarının burada ifade edilen durumu tam olarak yansıtamadığı ortadadır. Nitekim Gömleksiz (2005) ders kitaplarının yapılandırmacı felsefeye göre hazırlanması gerekirken klasik, idealist, realist yaklaşıma göre düzenlendiğini söylemektedir. Ders kitaplarının yapılandırmacı felsefe çerçevesinde geliştirilmesi müfredatın hedeflediği matematiksel beceriler ve hatta üst düzey matematiksel beceriler için gereklidir. Soyutlama da diğer matematiksel becerileri yapısında barındırdığından ötürü üst düzey bir matematiksel beceri olarak nitelendirilebilir. Sonuç olarak soyutlamanın gelişimi ile ders kitaplarının felsefesinin yakından ilişkili olduğu düşünülmektedir.

\section{Öneriler}

Ders kitaplarında konu anlatımlarının dışında sadece etkinlikler yer almamaktadır. Bunun yanında değerlendirme soruları, problem kurma ve çözme durumları, sorular, örnek durumlar yer almaktadır. Bu çalışmada sadece uygulama basamakları bulunan etkinlikler incelenmiştir. Sonraki çalışmalar da ders kitabında öğretime dâhil tüm durumlar analiz edilebilir.

İncelenen etkinliklerin günlük hayatla ilişkisinin asgari düzeyde kaldığ 1 fark edilmiştir.

Etkinliklerin günlük hayatla ilişkilendirilmesi soyut matematiksel kavramların somutlaştırılmasını destekleyebilir. $\mathrm{O}$ halde etkinliklerin günlük hayatla iç içe hazırlanmasının matematiksel anlamayı sağlayacağı düşünülmektedir. Benzer şekilde sadece 7 . sınıftan bir etkinlikte sosyal sorumluluk ile ilgili etkinliğin yer aldığ 1 fark edilmiştir. Bu tarz örneklerin çoğaltılmasının faydalı olacağı söylenebilir.

Ders kitapları eğitim-öğretim sürecinde önemli bir yere sahiptir. Özellikle de öğrenci başarısını etkileyen materyallerin başında gelmektedir. Akdeniz'e (2004) göre yazılı dokümanların istenen düzeyde geliştirilmesi için ilgili konularda araştırmaların yürütülüp sonuçlarının göz önünde bulundurulması gerekmektedir. Dolayısıyla bu tarz çalışmaların farklı matematiksel becerilerle de yürütülüp literatüre dâhil edilmesinin fayda sağlayacağ düşünülmektedir.

\section{Etik Kurul Onay Bilgileri}

Çalışma doküman incelemesi olduğundan etik kurul onayı gerekmemektedir.

\section{Kaynaklar}


Aç11, E. (2015). Ortaokul 3. sını öğrencilerin denklem kavramına yönelik soyutlama süreçlerinin incelenmesi: APOS Teorisi (Yayımlanmamış doktora tezi). Atatürk Üniversitesi, Eğitim Bilimleri Enstitüsü, Erzurum.

Akdeniz, A. R. (2004). Konu alanı ders müfredatı incelenmesi dersinde yürütülen etkinlikler ve kazandırılan davranışların değerlendirilmesi. Eğitim ve Bilim, 29(134), 11-18.

Altaylı, D. (2018). Ortaokul ögrencilerinin çokgenler konusundaki soyutlama süreçlerinin incelenmesi: $R B C+C$ modeli (Yayımlanmamış doktora tezi). Atatürk Üniversitesi, Eğitim Bilimleri Enstitüsü, Erzurum.

Altun, M., Arslan, Ç. ve Yazgan, Y. (2004). Lise matematik ders kitaplarının kullanım şekli ve sıklığı üzerine bir çalışma. Uludağ Üniversitesi Eğitim Fakültesi Dergisi, 17(2), 131-147.

Ayvacı, H. S., Çepni, S. ve Akdeniz, A. R. (1999). Fizik ders kitaplarının değerlendirilmesi. III Ulusal Fen Bilimleri Eğitimi Sempozyumu Kitapçı̆̆ı, 129-136.

Brousseau, G. (1986). Fondements et méthodes de la didactique des mathématiques. Recherches en Didactique des Mathématiques, 7(2), 33-115.

Camci, F. (2018). Altıncı sınıf öğrencilerinin tahmini öğrenme yol haritası çerçevesinde tasarlanan bir öğretim deneyindeki matematiksel soyutlama süreçleri (Yayımlanmamış yüksek lisans tezi). Anadolu Üniversitesi, Eskişehir.

Chambers, P. ve Timlin, R. (2013). Teaching mathematics in the secondary school (2nd ed). London: Sage Publications.

Collopy, R. (2003). Curriculum materials as a professional development tool: How a mathematics textbook affected two teachers' learning. The Elementary School Journal, 103(3), 287311.

Corbin, J. ve Strauss, A. (2008). Basics of qualitative research: Techniques and procedures for developing grounded theory. Thousand Oaks: Sage.

Çetin, İ. (2009). Students' understanding of limit concept: An APOS perspective. (Unpublished Doctoral dissertation). Middle East Technical University, Ankara.

Çimen, E. E. ve Yıldız, Ş. (2017). Ortaokul matematik ders kitaplarında yer verilen problem kurma etkinliklerinin incelenmesi. Turkish Journal of Computer and Mathematics Education, 8(3), 378-407.

Deniz, K. ve Karagöl, E. (2018). Değerler eğitimi açısından ortaokul Türkçe ders kitapları. Karaelmas Eğitim Bilimleri Dergisi, 6(2), 244-255.

Dienes, Z. P. (1967). On abstraction and generalization. Harvard Educational Review, 31(3), 281301.

Dubinksy, E. (2000). Mathematical literacy and abstraction in the 21st century. School Science and Mathematics, 100(6), 289-97

Dubinsky, E. (1991). Reflective abstraction in advanced mathematical thinking. D. Tall (Yay. haz.), Advanced Mathematical Thinking, içinde (ss. 95-123). Dordrecht, The Netherlands: Kluwer. Erişim adresi: http://www.math.wisc.edu/ wilson/Courses /Math903/ReflectiveAbstraction.pdf.

Fan, L. (2013). Textbook research as scientific research: towards a common ground on issues and methods of research on mathematics textbooks. ZDM, 45(5), 765-777.

Fan, L. (2011, October). Textbook research as scientific research: Towards a common ground for research on mathematics textbooks. International Conference on School Mathematics Textbooks.

Ferrari, P. L. (2003). Abstraction in mathematics. Philosophical Transactions of the Royal Society of London B, 358(1435), 1225-1230.

Gümüşoğlu, F. (2014). Ders kitaplarında toplumsal cinsiyet. Toplum ve Demokrasi Dergisi, 2(4), 39-50.

Harel, G. ve Sowder, L. (1998). Students' proof schemes: Results from exploratory studies. A. Schoenfeld, J. Kaput ve E. Dubiensky (Yay. haz.), Research in collegiate mathematics education III içinde (ss. 234-283). Providence, R. I.: American Mathematical Society. 
Herbel-Eisenmann, B. A. (2007). From intended curriculum to written curriculum: Examining the "voice" of a mathematics textbook. Journal for Research in Mathematics Education, 38(4), 344-369.

Hong, D. S., Choi, K. M., Runnalls, C. ve Hwang, J. (2018). Do textbooks address known learning challenges in area measurement? A comparative analysis. Mathematics Education Research Journal, 30(3), 325-354.

Işık, A. ve Konyalığlu, A. C. (2005). Matematik eğitiminde görselleştirme yaklaşımı. Atatürk Üniversitesi Kazım Karabekir Ĕgitim Fakültesi Dergisi, (11), 462-471.

Johansson, M. (2003). Textbooks in mathematics education: a study of textbooks as the potentially implemented curriculum (Licentiate thesis). Luleå: Department of Mathematics, Luleå University of Technology.

Kabael, T. (2011). Tek değişkenli fonksiyonların iki değişkenli fonksiyonlara genellenmesi, fonksiyon makinesi ve APOS. Kuram ve Uygulamada Eğitim Bilimleri, 11(1), 465-499.

Kaya, Z. (2002). Uzaktan eğitim. Ankara: Pegem A Yayıncılık.

Kılıç, A. ve Seven, S. (2005). Konu alanı ders kitabı incelemesi. Ankara: Pegem A Yayıncılık.

Memnun Sezgin, D. ve Altun, M. (2012). Matematiksel başarı düzeyleri farklı iki altıncı sınıf öğrencisinin koordinat sistemini soyutlamaları üzerine bir örnek olay çalışması. Elektronik Sosyal Bilimler Dergisi, 11(41), 34-52.

Miles, M. B. ve Huberman, A. M. (1994). Qualitative Data Analysis (2 ${ }^{\text {nd }}$ ed), CA: Sage Publications.

Milli Eğitim Bakanlığı [MEB]. (2018). İlköğretim Matematik 5 Ders Kitabı. Ankara: SDR Dikey Yayıncilik.

Milli Eğitim Bakanlığ1 [MEB]. (2018). İlköğretim Matematik 6 Ders Kitabı. Ankara: Berkay Yayıncilik.

Milli Eğitim Bakanlığı [MEB]. (2018). İlkögrretim Matematik 7 Ders Kitabı. Ankara: Koza Yayınc1lik.

Milli Eğitim Bakanlığı [MEB]. (2018). Illköğretim Matematik 8 Ders Kitabı. Ankara: Ekoyay Eğitim Yayınc1lık.

Milli Eğitim Bakanlığı, Talim ve Terbiye Kurulu Başkanlığı (2018). Illkokul ve ortaokul matematik dersi ögretim programı. Ankara: MEB.

Milli Eğitim Bakanlığı (2012). Millî Eğitim Bakanlığı Ders Kitapları ve Eğitim Araçları Yönetmeliği. Erişim adresi: https://www.resmigazete.gov.tr/eskiler/2012/09/201209122.htm

Mitchelmore, M. ve White, P. (2007). Abstraction in mathematics learning. Mathematics Education Research Journal, 19(2), 1-9.

Murray, M. A. (2002). First-time calculus students discovering the product rule: function, notation and apos theory (Dissertation doctoral thesis). University at Albany, New York.

National Council of Teachers of Mathematics [NCTM]. (2000). Principles and standards for school mathematics. Reston, VA: NCTM.

Noss, R. ve Hoyles, C. (1996). Windows on mathematical meanings. Dordrecht, The Netherlands: Kluwer.

Olkun, S. veToluk Uçar, Z. (2012). Illkögretimde etkinlik temelli matematik ögrretimi (5. Bask1), Ankara: Eğiten Kitap.

Özmantar, M. F. (2004). Scaffolding, abstraction, and emergent goals. Proceedings of the British Society for Research into Learning Mathematics, 24(2), 83-89.

Reys, R., Lindquist, M. M., Lambdin, D. V. ve Smith, N. L. (2002). Helping children learn mathematics. John Wiley \& Sons: New Jersey.

Smith III, J. P., Males, L. M., Dietiker, L. C., Lee, K. ve Mosier, A. (2013). Curricular treatments of length measurement in the United States: Do they address known learning challenges? Cognition and Instruction, 31(4), 388-433.

Stein, M. K., Remillard, J. ve Smith, M. S. (2007). How curriculum influences student learning. Lester, F.K. (Yay. haz.), Second handbook of research on mathematics teaching and learning içinde (ss. 319-370). Greenwich, CT: Information Age Publishing. 
Tabaghi, S. G. (2007). APOS analysis of students' understanding of logarithms. a thesis in the department of mathematics and statistics. Teaching of Mathematics at Concordia University Montreal, Quebec, Canada.

Türk Dil Kurumu [TDK]. (2019). Erişim adresi: http://www.tdk.gov.tr/index.php?option=com_ gts\&arama=gts\&guid=TDK.GTS.5cb786d9dec0a2.00350088

Tsamir, P. ve Dreyfus, T. (2002). Comparing infinite sets- a process of abstraction: the case of Ben. Journal of Mathematical Behavior, 21, 1-23.

Tzirias, W. (2011). APOS theory as a framework to study the conceptual stages of related rates problems (Dissertation masters thesis). Concordia University, Canada.

Ubuz, B. ve Sarpkaya, G. (2014). İlköğretim 6. sınıf cebirsel görevlerin bilişsel istem seviyelerine göre incelenmesi: Ders kitapları ve sinıf uygulamaları. Illkögretim Online, 13(2), 595-606.

Valverde, G. A., Bianchi, L. J., Wolfe, R. G., Schmidt, W. H. ve Houang, R. T. (2002). According to the book: using TIMSS to investigate the translation of policy into practice through the world of textbooks. Dordrecht: Kluwer. Erişim adresi: https://books.google.com.tr/books?id=e48FwrR8IAQC\&printsec=frontcover\&hl=tr\&so urce $=\mathrm{gbs} \_g e$ summary_r $\&$ cad $=0 \# \mathrm{v}=$ onepage $\& \mathrm{q} \& \mathrm{f}=$ false

Wach, E. ve Ward, R. (2013). Learning about qualitative document analysis. Erişim adreesi: https://opendocs.ids.ac.uk/opendocs/handle/20.500.12413/2989.

Weller, K., Arnon, I. ve Dubinsky, E. (2009). Preservice Teachers' Understanding of the Relation between a Fraction or Integer and Its Decimal Expansion. Canadian Journal of Science, Mathematics and Technology Education, 9(1), 5-28.

Welling, H. (2007). Four mental operations in creative cognition: The importance of abstraction. Creativity Research Journal, 19(2-3), 163-177.

Williams, G. (2002, July). Associations between mathematically insightful collaborative behaviour and positive affect. PME Conference, içinde (cilt. 4, ss. 4-401).

Yaşar, O. (2005). Türkiye'de okutulan orta öğretim coğrafya ders kitaplarında ölçme ve değerlendirme çalışmalarına yönelik karşılaştırmalı bir yaklaşım. International Journal of Progressive Education, 1(2), 9-30.

Yıldırım, A. ve Şimşek, H. (2011). Sosyal bilimlerde araştırma yöntemleri. Ankara: Seçkin Yayınları.

Yılmaz, R. (2011). Matematiksel soyutlama ve genelleme süreçlerinde görselleştirme ve rolü (Yayınlanmamış doktora tezi). Uludağ Üniversitesi, Eğitim Bilimleri Enstitüsü, Bursa.

Zeybek, Z., Üstün, A. ve Birol, A. (2018). Matematiksel ispatların ortaokul matematik ders kitaplarındaki yeri. İlkögrretim Online, 17(3), 1317-1335.

\section{Extended Abstract}

\section{Introduction}

The history of studies on textbooks cannot be said to date back to many years. Studies started in 1955 and became more widespread. It has drawn attention that such studies have been conducted especially in the last 30 years. However, clay tablets made in the 3000 s before Christ are accepted as the first textbooks of the world. It is noteworthy that the use of textbooks that shape the countries' educational policies is so old and that their work is new.

In 1999, it was revealed that the books developed in our country did not meet the expectations of students and teachers; they did not reflect the characteristics such as timeliness, revitalization of abstract issues in the mind and directing to research. However, we may encounter many scientific studies claiming that textbooks are effective in determining success. Therefore, studies with textbooks are becoming more important. In addition, the fact that the results obtained by analyzing the textbooks will affect the education policies and the contribution of such a study is obvious. On the other hand, analyzing the textbook within the framework of the mathematical abstraction skills is also valuable in terms of the awareness that it will provide to teachers, researchers and educators about the concept of abstraction. In this research, it is tried to examine 
to what extent the activities in middle school textbooks allow students to use abstraction skills. According to the aim of the research, the problems that are sought are as follows:

1. How often does the abstraction ability take place in middle mathematics activities?

2. What are the levels of domains of learning activities in middle school mathematics to reflect the students' abstraction ability?

\section{Method}

This study was carried out by document review of qualitative research methods. These documents, the Ministry of National Education in the province of Hatay for the 2018-2019 academic years 58. grade textbook. There were 45 activities in the 5 th grade, 42 activities in the 6th grade, 47 activities in the 7th grade and 23 activities in the 8th grade. Thus, a total of 157 activities were the study group of the study. Activities were analyzed by descriptive analysis. In the analysis of activities, cognitive mechanisms (interiorization, coordination, encapsulation, generalization, reversal) intended to reveal the idea of abstraction was used as a category. In order to make sure that the activities were able to analyze the abstraction skills, another expert was able to analyze randomly selected activities and the researcher re-analyzed the analyzes for a while. In the first stage, the compliance percentage was determined as $84 \%$ among the experts. In cases where there is incompatibility, it is discussed until the consensus is reached.

\section{Results}

In the 5th, 7th and 8th grades, activities related to the most internalization activities were included and it was realized that the activities in the 5th and 7th grades were evaluated in the least generalization category. The 6th grade activities were the least internalization and most generalized activities in contrast to the other grades. In addition, it was noticed that no activity at grade level had any actions related to reversal. Although most of the activities have cognitive concepts such as comparison, reflection, awareness, synthesizing and generalization related to abstraction, few (12.7\%) can provide abstraction skills. If we evaluate the findings in terms of grade, it is realized that 6th grade activities (31\%) represent the abstraction ability better than the activities of other grades.

Activities in the middle school mathematics textbooks have been discussed in terms of cognitive mechanisms of abstraction on the basis of areas of learning. Accordingly, it can be stated that there are activities ranging from internalization to generalization at each grade level, but if we evaluate the learning areas in it, it can be stated that activities in generalization type are not included in each learning area.

\section{Discussion and Conclusion}

Textbooks are one of the teaching materials that pioneered educational reforms. Therefore, the development of course materials for our country's policy, which aims at change and renewal in education, has an important place. In this study, the levels of mathematics activities reflecting the abstraction skills of middle school were investigated. For this purpose, each grade is examined separately on the basis of learning areas. It is observed that 20 out of 157 activities (31\%) in the middle school mathematics textbook were evaluated in the generalization category. Especially in the 5th and 7th grade, it is noteworthy that there are a few activities with generalization features.

The findings show that the actions related to abstraction at each grade level are at least at the basic level. Although some activities can be constructed in a way to support further mathematical abstraction, it is noteworthy that they are incomplete or incomplete. In some of the activities, students were expected to reach a general conclusion with just a correct example. This situation may also affect the ability to prove wrong. Confirming the correctness of the answer with acorrect example is one of the misperceptions in the proof process. Therefore, it is not right to expect to gain abstraction skills with activities that cause misconception.

As a result, it can be said that while the activities in the textbooks have the power and opportunity to reflect the abstraction actions in a better way, the activities are not adequately constructed within the framework of abstraction skill.Moreover, if we look at the actions of the 
Kilıçoğlu

categories related to abstraction, these actions are not only in abstraction skills, but also represent different mathematical skills such as association, proof, estimation, problem formation. Therefore, it will not be wrong to find that actions are not generally represented in sufficient number according to the data obtained. 